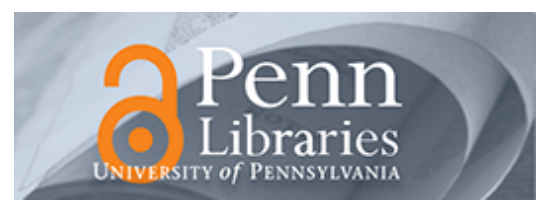

Manuscript Studies

\title{
Clockwise-Counterclockwise: Calligraphic Frames in Sephardic Hebrew Bibles and Their Roots in Mediterranean Culture
}

Dalia-Ruth Halperin

Talpiot College of Education, dalia-ruth.halperin@mail.huji.ac.il

Follow this and additional works at: https://repository.upenn.edu/mss_sims

Part of the Jewish Studies Commons, and the Near Eastern Languages and Societies Commons

\section{Recommended Citation}

Halperin, Dalia-Ruth (2019) "Clockwise-Counterclockwise: Calligraphic Frames in Sephardic Hebrew Bibles and Their Roots in Mediterranean Culture," Manuscript Studies: Vol. 4 : Iss. 2 , Article 2.

Available at: https://repository.upenn.edu/mss_sims/vol4/iss2/2 


\title{
Clockwise-Counterclockwise: Calligraphic Frames in Sephardic Hebrew Bibles and Their Roots in Mediterranean Culture
}

\author{
Abstract \\ Most Near Eastern and Sefardi Bible manuscripts feature calligraphic frames around many of their carpet \\ pages, and in Sefardi Iberian manuscripts they are frequently found surrounding the Temple Implement \\ pages, which are unique to the region. The present essay traces the development of this scribal art in the \\ Iberian Peninsula and the way that it evolved into a regional phenomenon that mirrors cultural interests \\ and influences. I also discuss its origins in Hebrew Near Eastern manuscripts and further demonstrate \\ the cultural roots and origins of this scribal phenomenon in the surrounding Byzantine and Islamic \\ cultures.
}

\section{Keywords}

Manuscript studies, Sefardi Iberian manuscripts, Near Eastern manuscripts, Byzantine manuscripts, Islamic manuscripts, Cultural influences 
Halperin: Calligraphic Frames in Sephardic Hebrew Bibles

\section{MANUSCRIPT STUDIES}

A Journal of the Schoenberg Institute for Manuscript Studies

VOLUME 4, NUMBER 2

(Fall 2019)

Manuscript Studies (ISSN 2381-5329) is published semiannually

by the University of Pennsylvania Press

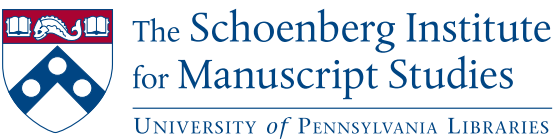




\section{MANUSCRIPT STUDIES}

VOLUME 4, N U M B E 2

(Fall 2019)

ISSN 2381-5329

Copyright (C 2019 University of Pennsylvania Libraries

and University of Pennsylvania Press. All rights reserved.

Published by the University of Pennsylvania Press, 3905 Spruce Street, Philadelphia, PA 19104.

Printed in the U.S.A. on acid-free paper.

Manuscript Studies brings together scholarship from around the world and across disciplines related to the study of premodern manuscript books and documents, with a special emphasis on the role of digital technologies in advancing manuscript research. Articles for submission should be prepared according to the Chicago Manual of Style, $16^{\text {th }}$ edition, and follow the style guidelines found at http://mss.pennpress.org.

None of the contents of this journal may be reproduced without prior written consent of the University of Pennsylvania Press. Authorization to photocopy is granted by the University of Pennsylvania Press for libraries or other users registered with Copyright Clearance Center (CCC) Transaction Reporting Service, provided that all required fees are verified with CCC and paid directly to CCC, 222 Rosewood Drive, Danvers, MA 01923. This consent does not extend to other kinds of copying for general distribution, for advertising or promotional purposes, for creating new collective works, for database retrieval, or for resale.

\section{SUBSCRIPTION INFORMATION:}

Single issues: $\$ 30$

Print and online subscriptions: Individuals: $\$ 40$; Institutions: $\$ 92$; Full-time Students: $\$ 30$ International subscribers, please add $\$ 19$ per year for shipping.

Online-only subscriptions: Individuals: $\$ 32$; Institutions: $\$ 80$

Please direct all subscription orders, inquiries, requests for single issues, address changes, and other business communications to Penn Press Journals, 3905 Spruce Street, Philadelphia, PA 19104. Phone: 215-573-1295. Fax: 215-746-3636. Email: journals@pobox.upenn.edu. Prepayment is required. Orders may be charged to MasterCard, Visa, and American Express credit cards. Checks and money orders should be made payable to "University of Pennsylvania Press" and sent to the address printed directly above.

One-year subscriptions are valid January 1 through December 31. Subscriptions received after October 31 in any year become effective the following January 1. Subscribers joining midyear receive immediately copies of all issues of Manuscript Studies already in print for that year.

Postmaster: send address changes to Penn Press Journals, 3905 Spruce Street, Philadelphia, PA 19104.

Visit Manuscript Studies on the web at mss.pennpress.org. 


\title{
Clockwise-Counterclockwise: Calligraphic Frames in Sephardic Hebrew Bibles and Their Roots in Mediterranean Culture
}

\author{
Dalia-Ruth HaLPeRin \\ Talpiot College of Education
}

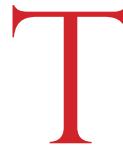

he Decoration program of Iberian Sephardic Bible manuscripts embraces two distinct scribal art forms: Masorab figuratel and epigraphic frames that surround full-page decorations penned in display-size square script and micrographic script—or both. ${ }^{1}$ These forms shape frames that surround carpet pages, Masoretic comparison tables, and Temple Implement pages, as well as word counts at the end of the various books of the Bible. The texts for these frames come from Masoretic listslexical texts that were created as a means for stabilizing and maintaining the accuracy of the biblical text. These lists contain information on vocalization, accentuation, cantillation, verse counts, notation of singular words, precise spelling of words (plene or defective orthography), their proper pronunciation, and for each word, the number of times it occurs in the Bible, with its specific spelling and accentuation, along with its loci. ${ }^{2}$ Verses

I thank my anonymous readers for their in-depth and enlightening comments.

1 Micrography (miniscule writing) became synonymous in art history research with the unique Jewish scribal art that forms the contour of various designs in the margins of Hebrew Masorated Bibles and other Hebrew illuminated manuscripts in miniscule script. When using “micrographic," I am referring to font size.

2 Leila Avrin, "The Illuminations in the Moshe Ben-Asher Codex of 895 CE," PhD thesis, University of Michigan at Ann Arbor (1975), 66-71; David Lyons, The Cumulative Masora: 
from the Bible, most often from Psalms, Proverbs, and Job, are at times used as well. Calligraphic frames are found in the earliest extant Bible manuscripts from the Near East and from all but the Italian diaspora. ${ }^{3}$ In Iberian Hebrew Bible manuscripts, the penning of such frames can be shown to have developed into distinct regional systems.

Calligraphic and micrography frames are elements of scribal art traditions that have endured through immigrant scribes in their new environs. ${ }^{4}$ However, there has not been any research to date on the typology of these frames or the significance of the variant choreographic systems for the penning that forms them. This essay is designed to illuminate the development of this scribal art in the Iberian Peninsula into a regional phenomenon that mirrors cultural interests and influences and to shed light on its external cultural roots in Hebrew Near Eastern manuscripts as well as in surrounding cultures. ${ }^{5}$

\section{Calligraphic Frames in Sephardic Iberian Manuscripts}

Three choreographies for penning frames are found in manuscripts from the Iberian Peninsula. In one of the two major systems, the writing begins

Text, Form and Transmission with a Facsimile Critical Edition of the Cumulative Masora in the Cairo Prophets Codex (Beer-Sheva: Ben-Gurion University of the Negev Press, 1999), 3-5; I. Yeivin, HaMasorab laMiqrab (The Biblical Masorah) (Jerusalem: Academy of the Hebrew Language, 2003), 114.

3 Hebrew manuscripts are delineated into five major codicological regions: Eastern/Oriental, Sephardic (which includes the Maghreb and the Iberian Peninsula), Byzantine, Ashkenazi, and Italian. On Hebrew codicology, see Malachi Beit-Arié, Hebrew Codicology: Historical and Comparative Typology of Hebrew Medieval Codices Based on the Documentation of the Extant Dated Manuscripts Using a Quantitative Approach, 73-81, available at http://web.nli.org.il/ sites/NLI/English/collections/manuscripts/hebrewcodicology/Pages/default.aspx (accessed 18 August 2018).

4 Malachi Beit-Arié, Hebrew Manuscripts of East and West: Towards a Comparative Codicology (London: British Library, 1993), 7; Beit-Arié, Hebrew Codicology, 56-59.

5 For a summary of the influence of acculturation and cultural transmission, including cultural repertoires on the shaping of the art of Jewish recipient cultures, see Katrin KogmanAppel, “Jewish Art and Cultural Exchange: Theoretical Perspectives," Medieval Encounters 17 (2011): 1-26. 
Halperin: Calligraphic Frames in Sephardic Hebrew Bibles

Halperin, Clockwise-Counterclockwise
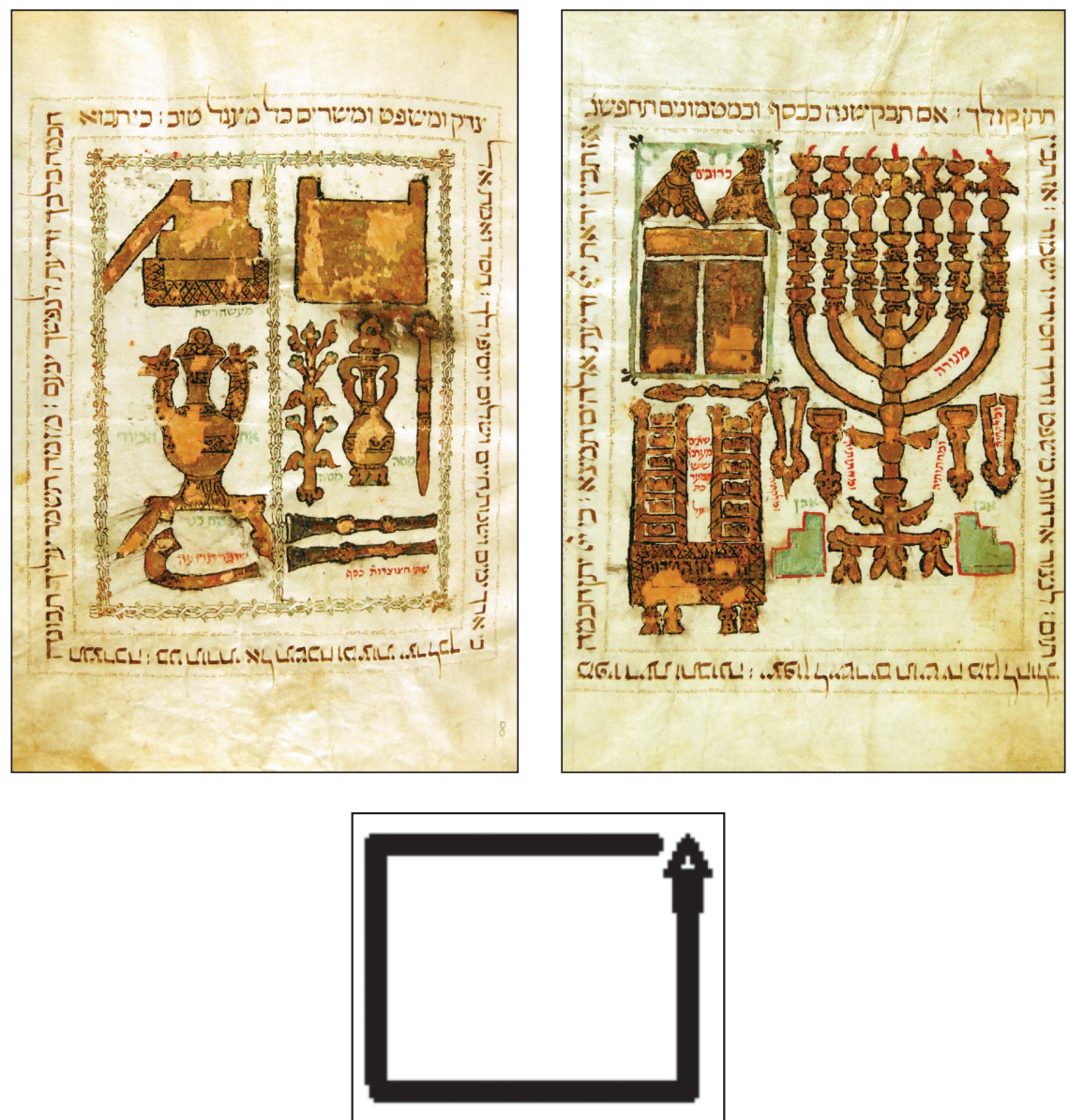

FIGU RE 1. Parma, Biblioteca Palatina, MS Parm. 2668, fols. 8r/7v, Toledo 1276/1277. Known also as the Toledo Bible or the First Parma Bible. The text moves in a counterclockwise position, as indicated in the diagram. Photograph by permission of Biblioteca Palatina, Parma.

at the top-right corner of the frame and continues in an uninterrupted flow back up to its starting point, so I call it "counterclockwise" (henceforth CCW) (fig. 1). This type of calligraphic frame is usually enclosed by frames in micrographic script that are also penned in a continuous line and are generally written counterclockwise from the top-right, leading to an upsidedown bottom line of text. However, in some manuscripts-for example, in Damascus Keter (Jerusalem, National Library of Israel, Heb 4790, fol. 114r, 
Manuscript Studies, Vol. 4 [2019], Iss. 2, Art. 2
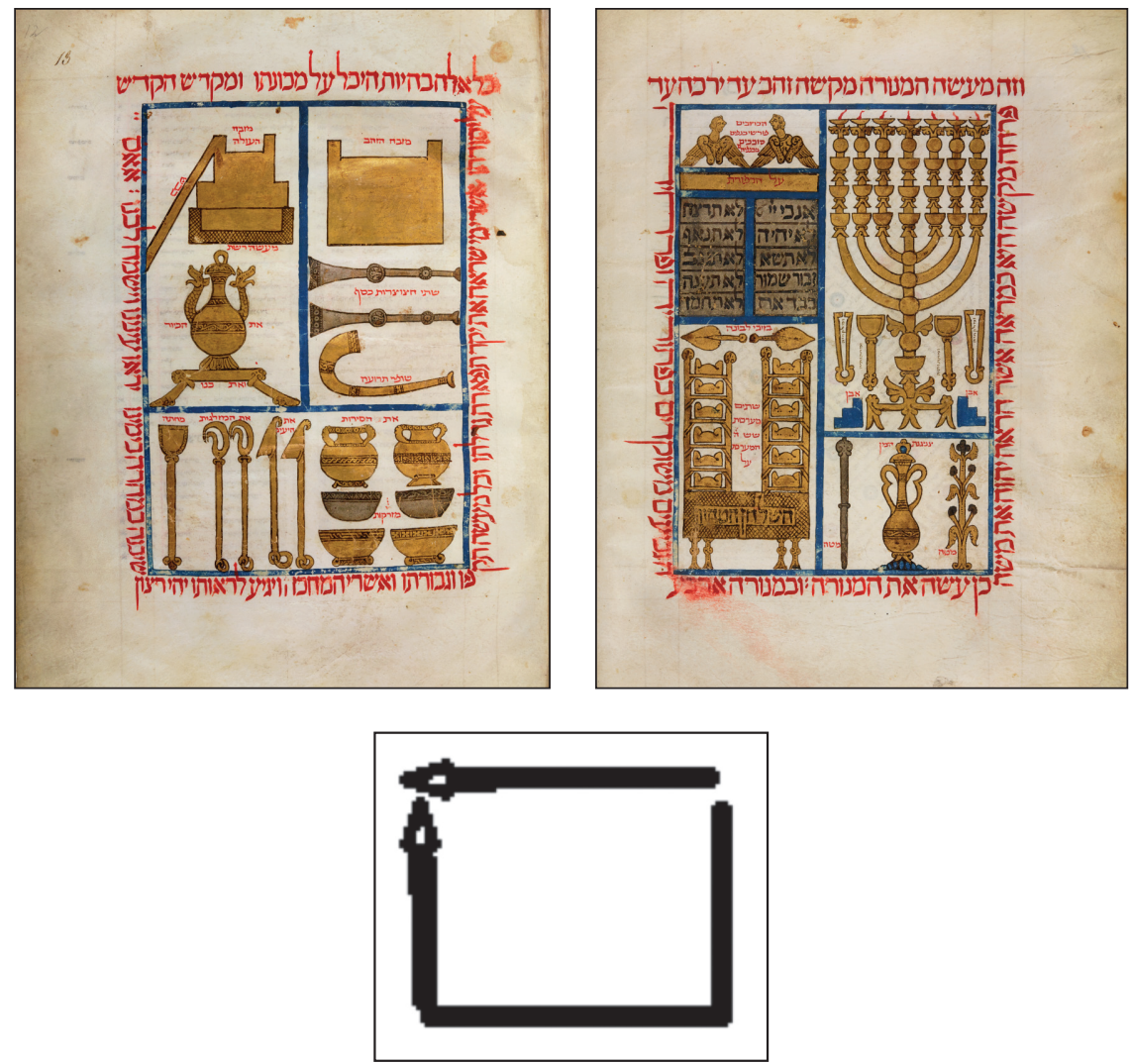

FIGURE 2. Paris, Bibliothèque nationale de France, MS Hébreu 7, fols. 13r/12v, Perpignan 1299. Known also as the Perpignan Bible. Here the text moves clockwise, as indicated in the diagram. Photograph by permission of Bibliothèque nationale de France, Paris.

Toledo[?], 1260) — the inner micrographic frame is penned from the bottomright corner, runs clockwise, and the top line of writing is overturned. ${ }^{6}$

The second major system begins as does the CCW system, at the topright corner, and goes to the top-left corner. The remaining three sides of the frame are then penned from the top-right corner in a continuous flow running clockwise. As this is its major flow, I call this system "clockwise" (henceforth CW) (fig. 2).

6 Damascus Keter (see fig. 4) is available at http://web.nli.org.il/sites/nlis/en/manuscript/ Pages/keter-damesek.aspx (accessed 17 May 2019). 
Halperin: Calligraphic Frames in Sephardic Hebrew Bibles

The third system, one that was utilized to a lesser degree in the Iberian Peninsula, is a combination of counterclockwise and clockwise penning. The writing begins as in the other systems, at the upper-right corner. From this point, half the frame runs counterclockwise to the bottom-left corner, and the other half runs clockwise. Thus, I call this system "counterclockwiseclockwise" (henceforth CCW-CW) (fig. 3).

Systematic classification of these frames reveals their regional affiliations. The Toledo Bible (Parma, Bibliotheca Palatina, MS Parm. 2668), Toledo, 1277, includes a set of folios surrounded with calligraphic frames. Among these folios are tables arranged in two columns (fols. $8 \mathrm{v}-9 \mathrm{r}$ ), a carpet page (fol. 9v), several blank pages (fols. $4 \mathrm{r}-7 \mathrm{v} ; 10 \mathrm{v}, 11 \mathrm{r}-\mathrm{v}, 12 \mathrm{r}$ ), and the earliest depiction found to date of the Sephardic Temple Implement page
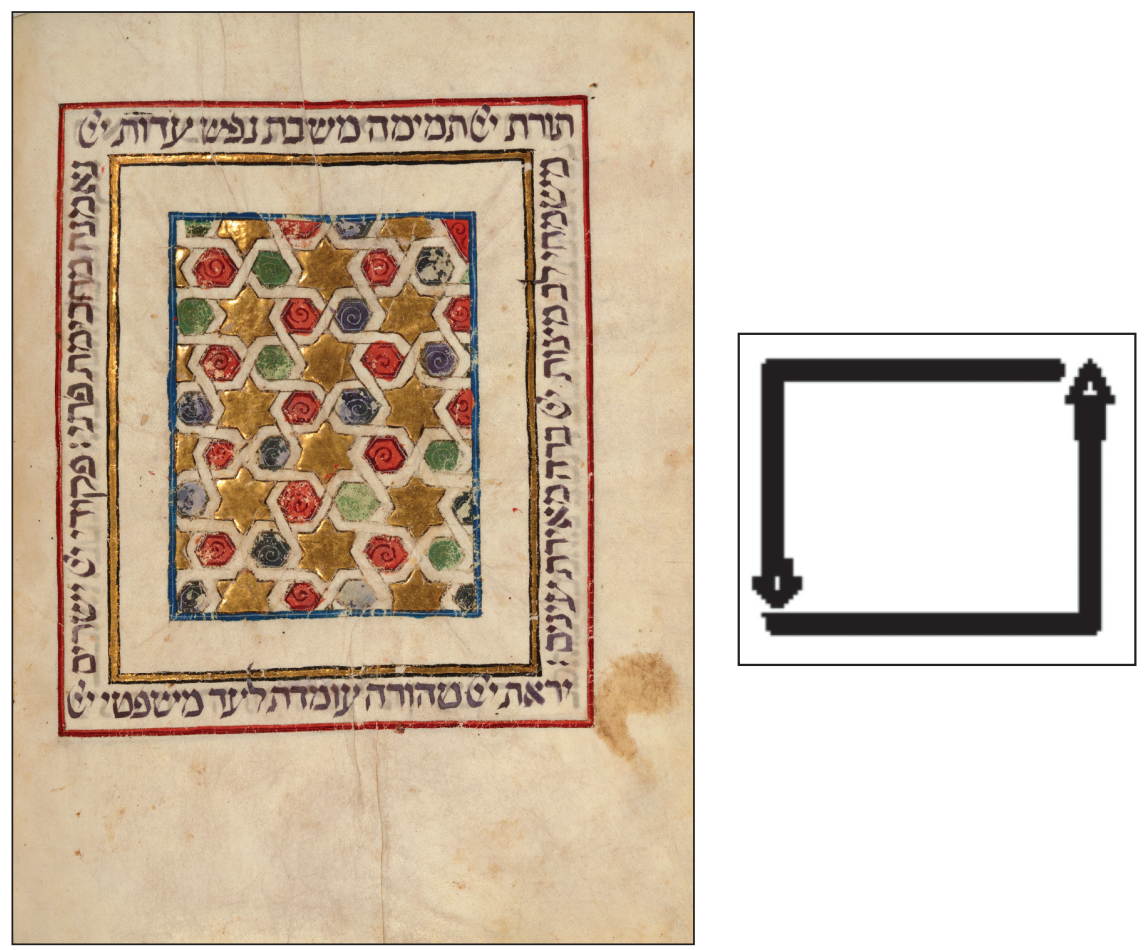

FIGURE 3. Paris, Bibliothèque nationale de France, MS Hébreu 21, fol. $98 \mathrm{v}$, Soria/Tudela 1300-1312. The text is in the counterclockwise-clockwise (CCW-CW) position, as shown in the diagram. Photograph by permission of Bibliothèque nationale de France, Paris. 
pattern (fols. $7 \mathrm{v}-8$; see fig. 1). ${ }^{7}$ Paleographical comparisons of both text and calligraphic frames leave no doubt that the latter were added by the scribe himself. ${ }^{8}$ The Toledo Bible served as the copying model for a group of six manuscripts, two of which are respectively dated 1299 and 1301, and were produced in Rousillon. The group is known as the "Toledan group" owing to the similar iconographical features reflected on the Temple Implement pages. ${ }^{9}$ Within this group, only the Toledo Bible evidences a CCW choreography for all its calligraphic frames. ${ }^{10}$ The other six manuscripts have a CW flow, but two of them carry some frames with a different choreography. In Modena, MS M.8.4, out of twenty-two calligraphic frames, nine have a CCW-CW flow, and in the King's Bible (British Library, MS Kings 1), two out of twelve

7 Katrin Kogman-Appel, Jewish Book Art Between Islam and Christianity: The Decoration of Hebrew Bibles in Medieval Spain (Leiden: Brill, 2004), 68-75; Dalia-Ruth Halperin, Illuminating in Micrography: The Catalan Micrography Mabzor, MS $8^{\circ} 6527$ in the National Library of Israel (Leiden: Brill, 2013), 98-100.

8 Binyamin Richler, ed., Hebrew Manuscripts in the Biblioteca Palatina in Parma Catalogue, with paleographical and codicological descriptions by Malachi Beit-Arié (Jerusalem: Hebrew University of Jerusalem, Jewish National and University Library, 2001), entry 3.

9 The manuscripts are: the Perpignan Bible (Paris, Bibliothèque nationale de France, MS Hébreu 7), produced in Roussillon in 1299; the Second Copenhagen Bible (Copenhagen, Kongelige Bibliotek, Cod. Heb. II), dated to 1301; Modena, Biblioteca Estense, MS T.3.8; and MS M.8.4; and the Frankfurt Bible, formerly Frankfurt-am-Main, Stadtbibliothek, Ausst. 4 (currently in a private collection). Owing to its iconographical similarities, the King's Bible (London, British Library, MS Kings 1), produced in Solsona in 1383, is also considered to be part of this group, although the menorah is placed separately on a single page. See KogmanAppel, Jewish Book Art Between Islam and Christianity, 68-70, 131-33; Bezalel Narkiss and Gabrielle Sed-Rajna, Index of Jewish Art: Iconographical Index of Hebrew Illuminated Manuscripts, vol. 5: Illuminated Manuscripts of the Collection at the Royal Library, Copenhagen (Copenhagen: The Royal Danish Academy of Sciences and Letters; Jerusalem: The Center for Jewish Art, the Hebrew University; and Paris: Institut de recherche et d'histoire des textes, 1994), card 250; Halperin, Illuminating in Micrography, 98-100.

10 Temple Implement pages are found primarily in Catalan manuscripts. As Temple Implement decorations in the Toledo Bible do not interface with the frames, they cannot help us determine whether the illustration of the Temple Implements themselves were drawn when the manuscript was produced in Castile or, as concluded by Joseph Gutmann, were added in Perpignan. See Joseph Gutmann, "The Messianic Temple in Spanish Medieval Hebrew Manuscripts," in The Temple of Solomon, ed. Joseph Gutmann (Missoula, MT: Scholars Press for American Academy of Religion, 1976), 135n6, 138-39. On this manuscript, see also Kogman-Appel, Jewish Book Art Between Islam and Christianity, 68-75. 
calligraphic frames have the CCW flow, as in the Toledo Bible. ${ }^{11}$ As the Temple implements are spread out in a slightly different fashion in these two manuscripts, and they also carry variant choreography of calligraphic frames, the question arises as to whether they reflect regional variations.

Another group of eight manuscripts from the Catalan or Roussillon region, which was under Catalan rule, have shared elements on their Temple Implement pages, and they carry only CW choreography for their calligraphic frames. ${ }^{12}$ Further analyses of other manuscripts from Castile and Catalonia, indicated in the appendix, support the suggestion that the mise en cadre (setting into a frame form) of calligraphic frames indicates that the CW method was typical of Catalonia, whereas the CCW system was characteristic of Castile. ${ }^{13}$ Another feature distinguishes between the Castilian and Catalan calligraphic frames: the Castilian frames are usually flanked by additional frames formed by micrography. The outer frame conforms to the direction of the display script, whereas the inner micrography frame, as noted above, runs CW (fig. 4). We seldom find micrographic frames in Catalan manuscripts, but when they do appear, they form double frames

11 Until the death of Jaime I, it was part of the Crown of Aragon; from 1275 to 1348 it was part of the Kingdom of Mallorca, but later was returned to Catalan rule. In terms of Jewish culture, these regions continued to be part of Jewish Catalonia. See Yom-Tov Assis, "The Jews in the Crown of Aragon and Its Dominions," in Moreshet Sepharad: The Sephardi Legacy, ed. Haim Beinart, vol. 1 (Jerusalem: Magnes Press, 1992), 44-46; Yom-Tov Assis, The Golden Age of Aragonese Jewry (London: The Littman Library of Jewish Civilization in association with Liverpool University Press, 1997), 190.

12 The manuscripts are: the Rome Pentateuch (Rome, Biblioteca della Comunità Israelitica, MS 3, Barcelona, 1325); the Istanbul Pentateuch dated 1336 held at Karaite Synagogue in Istanbul, in which the text appears above a decorative frame; the Cairo Pentateuch (Cairo, Gottheil 17); the Enrico Nabum Bible (Jerusalem, National Library of Israel, Heb 45147); the Foa Bible (Paris, Compagnie des prêtres de Saint-Sulpice, MS 1933); Paris, École nationale supérieure des beaux-arts, Mn. Mas. 4; Paris, Bibliothèque nationale de France, MS Hébreu 1314[-15]; the Farbi Bible (formerly Sassoon Collection, MS 368), dated 1366-82, in which the frames encompass an opening rather than a single folio. On Roussillon under Catalan rule in terms of Jewish culture being part of Jewish Catalonia, see J. F. O'Callaghan, $A$ History of Medieval Spain (Ithaca: Cornell University Press, 1975), 215-26, 245-49, 345-49, 362-63; Assis, "The Jews in the Crown of Aragon and Its Dominions," 44-46; Assis, Golden Age of Aragonese Jewry, 190.

13 See Appendix 1 for a chronological listing of the manuscripts. 


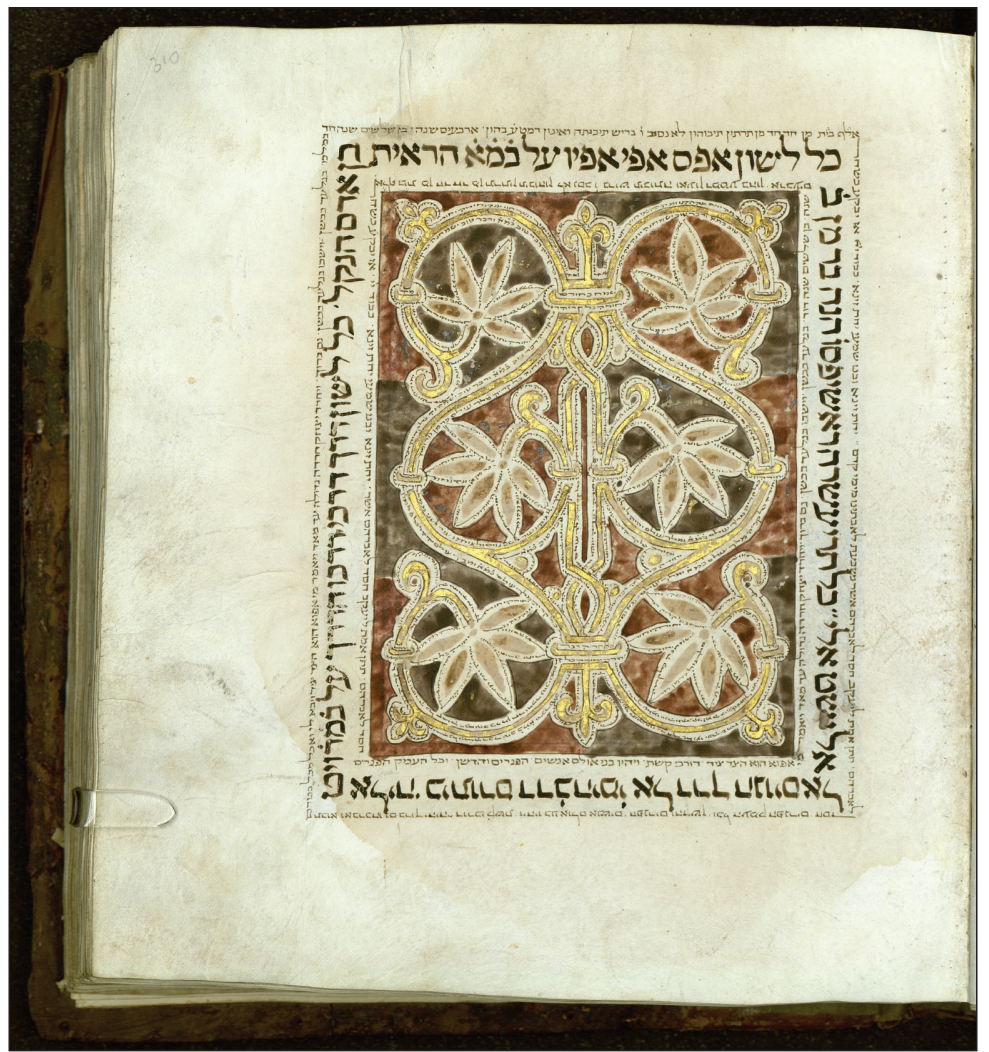

FIGU RE 4. Jerusalem, National Library of Israel, Heb 4²790, fol. 310r, Burgos 1260. Known also as the Damascus Keter. Photograph courtesy of The National Library of Israel, Jerusalem.

that surround the display script with an identical penning flow that is either CCW or CW (fig. 5).

Reexamining the third system, the one characterized by a CCW-CW flow, which is found in three of the seventeen Castilian manuscripts, we see that two were the work of the Yehoshu'a ibn Gaon, a scribe who was active in both Soria in Castile and Tudela in Navarre (see fig. 3). ${ }^{14}$ It is tempting to

14 The three manuscripts are Oxford, Bodleian Library, MS Kennicott 2, Soria/Tudela 1300; Paris, Bibliothèque nationale de France, MS Hébreu 21, Tudela 1301-2; Zurich, Braginsky Collection, MS 243, Ocaña 1491-Évora Portugal 1494. Yehoshua ibn-Gaon 


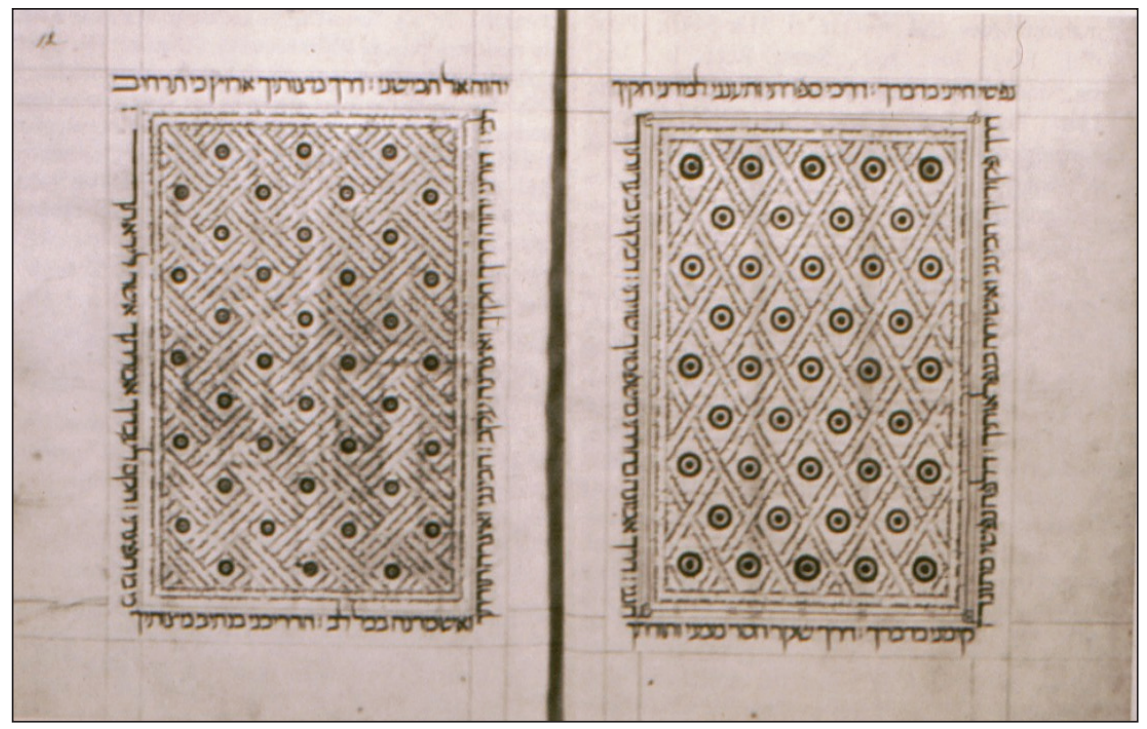

FIGURE 5. Paris, Bibliothèque nationale de France, MS Hébreu. 7, fols. 12r/11v, Perpignan 1299. Photograph by permission of Bibliothèque nationale de France, Paris.

see a Navarrese or at least a northern Castile system in these manuscripts. However, the scribe of the third manuscript in this group, Yitṣhaq ben Yishai ben Sasson, moved from Cordoba in the south to Ocaňa in the province of Toledo. ${ }^{15}$ As the scribe was from southern Iberia, and as it can be shown that scribes continued to adhere to their own scribal traits in their new environs, we may suggest that the $\mathrm{CCW}-\mathrm{CW}$ choreography might indicate that this method was utilized and known to some extent in the

belonged to a family of scribes and masorators from Soria, Castile. Of the seven manuscripts attributed to him, some were done in Soria and others a short distance to the northeast, in Tudela, Navarre. According to the colophons, it seems that he traveled between the two cities. The manuscripts attributed to him are: Lisbon, Biblioteca Nacional de Portugal, MS Il. 72; Paris, Bibliothèque nationale de France, MS Hébreu 20 and MS Hébreu 21; Dublin, Trinity College Library, MS 16; Oxford, Bodleian Library, MS Kennicott 2; Oxford, Bodleian Library, MS Oppenheim Add. 475-476; Parma, Biblioteca Palatina, MS Parm. 2938. See also Kogman-Appel, Jewish Book Art Between Islam and Christianity, 98-121.

15 The town is situated at the extreme northern end of the tableland known as the Mesa de Ocaña. 
Iberian Peninsula, although it was apparently not as widespread in use and eventually lost its prominence in the two major Jewish cultural centers.

Among Portuguese manuscripts known to have developed in the last third of the fifteenth century, presumably with origins in the Castilian school of illumination, the five dated manuscripts all have CCW calligraphic frames that are often surrounded by micrography frames, as is typical of manuscripts from Castile (fig. 6). ${ }^{16}$ We find a CCW-CW flow in only one out of twenty of these frames in a Portuguese manuscript (Philadelphia, Free Library, Lewis O 140) dated to Lisbon 1496. This might support the suggestion that the CCW-CW flow system was not in extensive use in the Iberian Peninsula.

A singular Valencian manuscript dated to 1290 (Parma, Bibliotheca Palatina, MS Parm. 3233) has calligraphic frames rendered in a CW Catalan system. Seemingly this corroborates the findings identifying this system with Catalonia, as Valencia had been under Catalan rule since 1245 and Catalan Jews who settled Valencia after it was conquered obviously brought their scribal traditions with them. Furthermore, the earliest extant documents written in a Valencian-Catalan dialect, which appeared at the turn of the fourteenth century, seemingly all attest to the Catalan origins of this manuscript. However, the scribe noted that he came from "Tetila"-Tudela in Navarre. This may be an indication that the CW system was also in use in Navarre, as it is unlikely that the scribe copied the dominant system in his new city; immigrant scribes generally continued to use their native scripts and adhered to their decorative scribal traditions. ${ }^{17}$ As Navarre frames usually demonstrate a CCW-CW flow, the use of a CW flow by a Navarrese scribe may suggest that apart from the particular and specific

16 This tradition was probably carried over with scribal migration westward after the destruction of Jewish communities at the turn of the fourteenth century and with the rise of the inquisition in Spain. See Joseph Gutmann, Hebrew Manuscript Painting (New York: George Braziller, 1978), 21; Bezalel Narkiss, Hebrew Illuminated Manuscripts (Jerusalem: Ketter, 1983), 28-29; Gabrielle Sed-Rajna, Les manuscrits hébreux enluminés des Bibliothèques de France (Paris : Bibliothèque nationale de France, 1994), 123-43; and Gabrielle Sed-Rajna, Manuscrits hébreux de Lisbonne (Paris: Centre National de la Recherche Scentifique, 1970).

17 Beit-Arié, Hebrew Manuscripts of East and West, 7; Beit-Arié, Hebrew Codicology. 

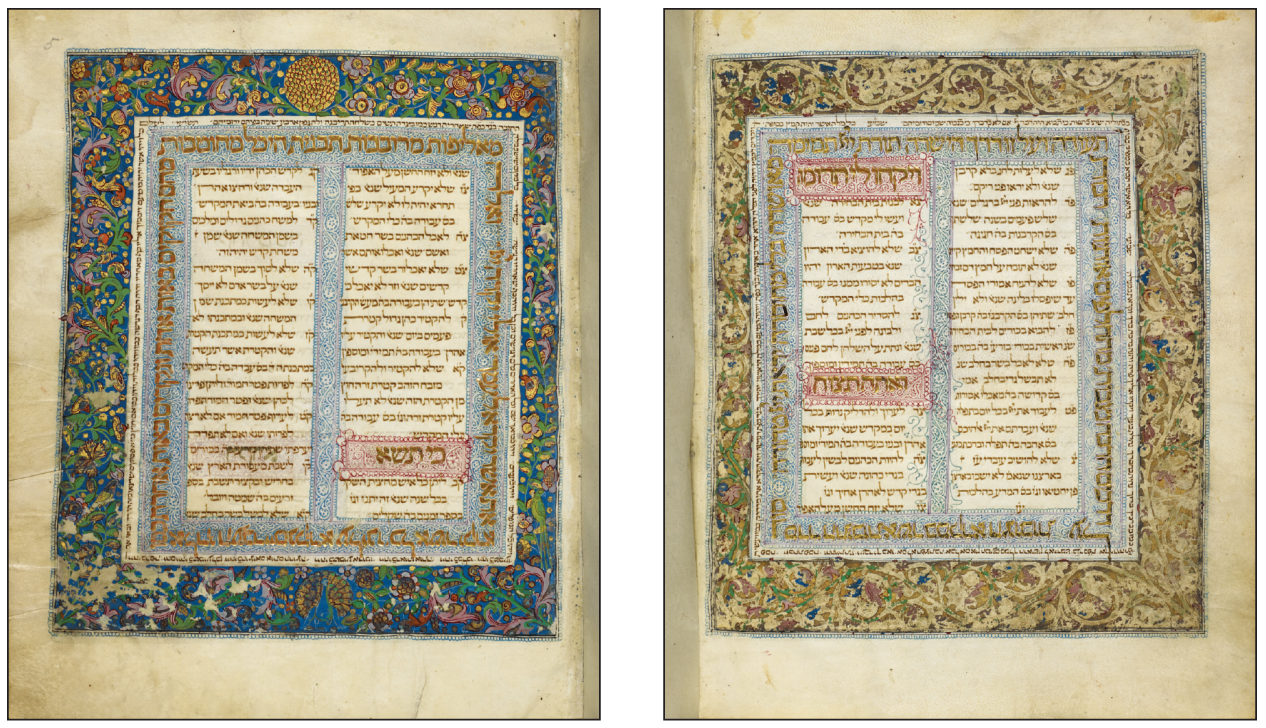

FIGURE 6. London, British Library, Or. 2626[-2628], fols. 5r/4v, Lisbon 1482. Known also as the Lisbon Bible. Photograph (C) The British Library Board, Or. 2626.

penning flow of the frames in each of the two major centers of Castile and Catalonia, a mix of calligraphic frame flows existed elsewhere.

To clarify this, we should look at the only two dated manuscripts from Aragon: Vatican City, Biblioteca Apostolica Vaticana, Ross. 601, from Huesca, dated to 1275, and Paris, Bibliothèque nationale de France, MS Hébreu 31, from Saragossa, dated to 1404. In the Vatican manuscript, out of the seven calligraphic frames, six run CCW, as was prevalent in Castile, but lack the Castilian micrography frames. Only one frame was drawn according to the CW system typical of Catalonia. The Paris manuscript also has CCW frames. As these two dated manuscripts were produced 130 years apart, we cannot determine definitive mise en cadre characteristics for Aragon with any certainty.

It is interesting to compare these two Aragonese manuscripts with the two from the Toledan group that carry calligraphic frames with a flow that is not strictly the CW Catalan system: in Modena, MS M.8.4, nine calligraphic frames out of twenty-two evidence the CCW-CW system typical of northern Castile/Navarre, and in the King's Bible (British Library, Kings 
MS 1) from Solsona, dated to 1383, two out of twelve calligraphic frames were drawn in the CCW flow that characterizes the Castilian manuscripts. Both of these manuscripts not only have a mélange of calligraphic frame flows, but also carry slight variations in the spread of the Temple Implements on the page. ${ }^{18}$ Might this mélange of calligraphic frame flows allow for a determination of either an Aragonese or Navarrese origin?

Comparing these manuscripts with Haverford College, Rendel Harris 1, dated to 1266 , sheds further light on the characteristics and import of this mélange of calligraphic frame flows. The Haverford manuscript has both $\mathrm{CCW}-\mathrm{CW}$ choreographies around carpet pages at the beginning of the manuscript and frames with Catalan CW flow around the carpet pages at the end of the manuscript. It is written in three text columns with thirty lines. As the manuscript was cropped in the course of a subsequent rebinding, its page size does not reflect its original characteristics. However, comparing its text measurement ratio, three columns of text and thirty text lines in SfarData, the Hebrew Paleography Project of the Israel Academy of Sciences in Jerusalem, revealed its close similarity to Biblioteca Apostolica Vaticana, Ross. 601, Huesca 1275, and a nearly exact ratio with National Library of Israel, Heb $4^{\circ} 790$, the Damascus Crown from Burgos dated to 1260. ${ }^{19}$ But does this allow us to place Haverford in Aragon, as the choreography of its calligraphic frames is not the same? Haverford, as noted above, does not carry the Castilian CCW system used in both Ross. 601 and Heb $4^{\circ} 790$ alongside the Catalan CW flow, but rather the CCW-CW flow

18 Halperin, Illuminating in Micrography, 92-105.

19 See SfarData 0E145 for Biblioteca Apostolica Vaticana, Ross. 601; SfarData 0A008 for National Library of Israel, Heb $4^{\circ} 790$; and SfarData 0D185 for Haverford College, Rendel Harris 1. It is interesting to note that three columns of text are common to 186 manuscripts, of which 141 are Bibles. Whereas most of these Bibles are Oriental, with this system prevalent there until the thirteenth century, three columns began appearing a century earlier in Ashkenazi Bibles and some Italian and Iberian Bibles as well. Of seventeen dated manuscripts that carry three columns and thirty lines, only those mentioned and one much later manuscript from Alba de Tormes in Castile dated 1487 (Hamburg, Staats -und Universitätsbibliothek, Cod. Hebr. 45; SfarData 0G179) are from Iberia. All of the others are mostly found in Ashkenazi Bibles. I am most grateful for this information and assistance on this issue offered by Tamar Leiter, codicology researcher at the Israel Academy of Sciences and Humanities Hebrew Paleography Project in Jerusalem and the SfarData coordinator. 
characteristic of northern Castile/Navarre. Reconsidering the calligraphic frames of Haverford College, Rendel Harris 1 in comparison with Modena, MS M.8.4, in which nine calligraphic frames out of twenty-two run CCW$\mathrm{CW}$ and the remainder are CW, as in the Catalan flow, might suggest a link to northern Castile/Navarre. ${ }^{20}$ It is also interesting to note that the order of biblical books in Rendel Harris 1 is as noted in the Talmud Baba Batra 14:2: first prophets arranged in a sequence of consolation, Jeremiah, Ezekiel, and Isaiah-an arrangement not common to Iberia but usually found in Ashkenazi Bibles. Might this strengthen the ascription of this manuscript to the northern region? Taking all this into account along with the Tudela/ Navarre origin of the scribe of the singular 1290 Valencian manuscript, which has a CW Catalan system, would suggest that Navarrese scribes might have used both CCW-CW and CW flows. This would explain the ease with which a Navarrese scribe working in Catalonia was able to work according to the system that was dominant in that region.

These findings suggest that perhaps the calligraphic frames in Sephardic Iberian Peninsula manuscripts can be sorted into coherent writing systems only in association with the major regions of Castile and Catalonia. Although Navarre and northern Castile seem to share a system that might have been familiar throughout Iberia, as is also evident in the work of the scribe originally from Cordoba (Zurich, Braginsky Collection, MS 243, ex-Botfield MS 1), manuscripts from Navarre and Aragon evidence a mélange of systems, making it difficult to distinguish between these regions. Navarrese manuscripts seem to evidence both the CCW-CW and CW flows, whereas those from Aragon display the mélange of CCW and CW systems. Clearly, this finding is important not only as a codicological tool that can assist in further sorting of manuscripts into their respective regions, but also as it illuminates the cultural influence of Castile and Catalonia, the two strongholds of Sephardic learning, on the neighboring Navarre and Aragon. ${ }^{21}$

20 Katrin Kogman-Appel identified the manuscript to be similar in style to the Roussillon atelier group. See Kogman-Appel, Jewish Book Art Between Islam and Christianity, 137-38.

21 On oral interscholastic transmission between the Barcelonan and Castilian schools of Kabbalah, see Haviva Pedaya, Nabmanides: Cyclical Time and Holy Text (Tel Aviv: Am Oved, 2003), 113-15. 


\section{The Developmental Roots of Calligraphic Frames}

At present, there are no extant dated decorated Hebrew manuscripts from Islamic Spain. Elsewhere, I have suggested that, based on paleographic and stylistic assessments, St. Petersburg, National Library of Russia, Evr. II B 116 might be an eleventh-century Sephardic manuscript from Islamic Iberia. The manuscript is decorated with vegetal and floral motifs similar to those in the mihrab of the Great Mosque of Cordoba (961-76). However, as it does not have calligraphic frames, it cannot shed any light on whether the developmental stages of calligraphic frames under discussion can be found in an Islamic setting. ${ }^{22}$

Research has shown that the roots of Sephardic script and manuscript decoration can be found in Near Eastern and Maghreb manuscripts. Indeed, comparisons between these and Iberian Sephardic manuscripts reveal this to be the case from the earliest extant decorated Hebrew manuscripts from the Iberian Peninsula, which date to the thirteenth century. ${ }^{23}$ Thus we may assume that the mise en cadre in the Near Eastern Hebrew manuscripts can shed light on the developmental stages of the Iberian systems. As manuscripts from these regions, in turn, reflect the tradition of Islamic book art, we must look at that as well. ${ }^{24}$

Reviewing Near Eastern Bible manuscripts with calligraphic frames, at first glance, seems to support the presence of CCW-CW flow in the frames. However, reading the inscriptions in an attempt to confirm the correspondence between writing flow and reading direction reveals that the reading flow, more often than not, does not correspond to the direction of penning

22 Halperin, Illuminating in Micrography, 86-87.

23 Malachi Beit-Arié, "Hebrew Script in Spain: Development, Offshoots and Vicissitudes," in Beinart, Moreshet Sepharad, 286-91; Beit-Arié, Hebrew Codicology, 77-70; Kogman-Appel, Jewish Book Art Between Islam and Christianity, 18-21; Gutmann, Hebrew Manuscript Painting, 28.

24 On the major influence Islamic art had on the decoration of Hebrew Bibles, see Joseph Gutmann, "Masorah Figurata: The Origins and Development of a Jewish Art Form," in Sacred Images: Studies in Jewish Art from Antiquity to the Middle Ages (Northampton: Variorum Reprints, 1989), 51; Gabrielle Sed-Rajna, “Toledo or Burgos,” Journal of Jewish Art 2 (1975): 6-21; Kogman-Appel, Jewish Book Art Between Islam and Christianity, 34-50, 54-56, 95-97. 
implied by the visual orientation of the calligraphic frames. Detecting the reading and penning flow is facilitated where there are successive verses. Occasionally a verse continues over more than one side of the frame or an opening, which simplifies the detection of the choreography. An example of this can be seen in a Masoretic list that pertains to the word brakba (blessing) in National Library of Russia, Evr. II B 1548, fol. 6r, dated 926-1000. ${ }^{25}$ On this page the CCW-CW system begins at the bottom-right corner, and we can discern the writing direction from the verses that span more than one side of the frame. In this manuscript the outer frame is formed from three verses: 2 Samuel 2:4, which runs from the bottom of the right side counterclockwise to the end of the top line; Genesis 33:11, which runs across the bottom clockwise to the left; and Leviticus 25:21, which continues on the frame's left side. The inner frame is formed by Exodus 23:25, which runs from bottom of the right side to the top, and Deuteronomy $15: 4$, penned from the bottom row to the left side. It is impossible to determine the order of the scribe's penning of the double frame from these data, as the penning does not exhibit a clear logical sequence. This suggests that the conflict between reading flow and the direction of penning implied by the visual orientation of the calligraphic frames suggests that Eastern manuscripts reveal the initial forming stage of this scribal art decoration.

Moreover, in other manuscripts, reading clashes with what one assumes is the direction of writing flow based on its visual manifestations. For example, in Cairo, Karaite Synagogue Gottheil 14, folio 2r, the verses from Isaiah 43:1-5 are penned with verses 43:1-3 on the top line. The last segment of verse 3 and the beginning of verse 4 , which are penned on the left side of the frame, are followed on the right side of the frame with the rest of verse 4 and verse 5 (fig. 7). This would indicate that the direction

25 The masorator-Azriqam-relates to the masorete Aharon Ben-Asher, who is known to have worked in the first half of the tenth century. Although the manuscript indicates a date of 921 Basra, Malachi Beit-Arié has concluded that the attribution was falsified and that the manuscript's true date could be 1022. See SfarData list ZR077 in Malachi Beit-Arié, Colette Sirat, and Mordehai Glazer, Codices hebraicis litteris exarati quo tempore scripti fuerint exbibentes (Turnhout: Brepols; Paris Institut de recherche et d'histoire des textes, CNRS; Jerusalem: Académie nationale des sciences et des lettres d'Israel, 1997), 1:3. 


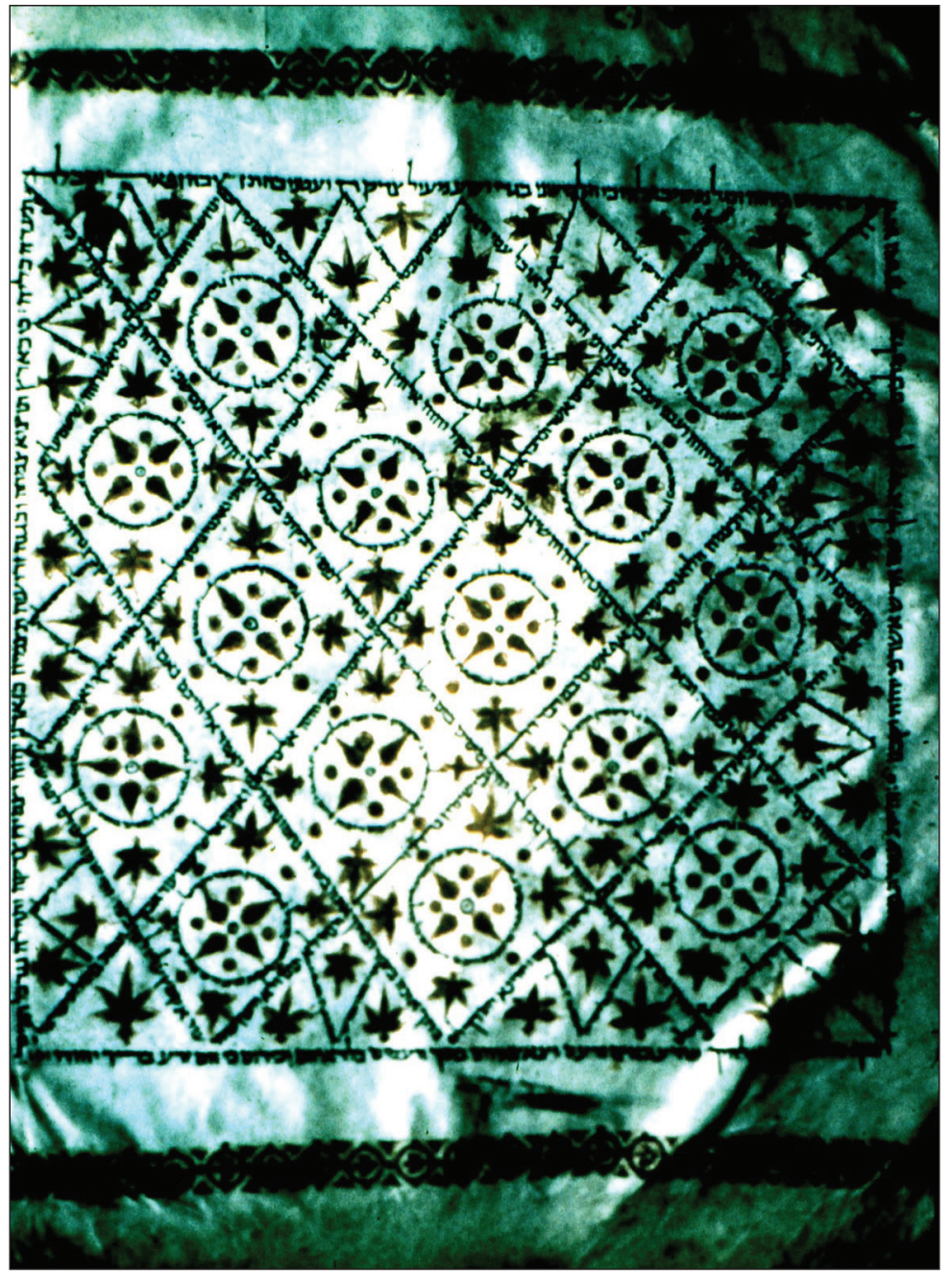

FIGURE 7. Cairo, Karaite Synagogue, Gottheil 14, fol. 2r. Photograph courtesy of The Universal Karaite Judaism.

of reading is counterclockwise, as must have been the choreography of the penning, although visually the writing direction seems to manifest a CCW-CW system.

In most of the examined manuscripts from the Near Eastern region, the calligraphic frames are not necessarily made up of successive verses. Moreover, inscriptions consist of single verses fitted to the side of the frame their 


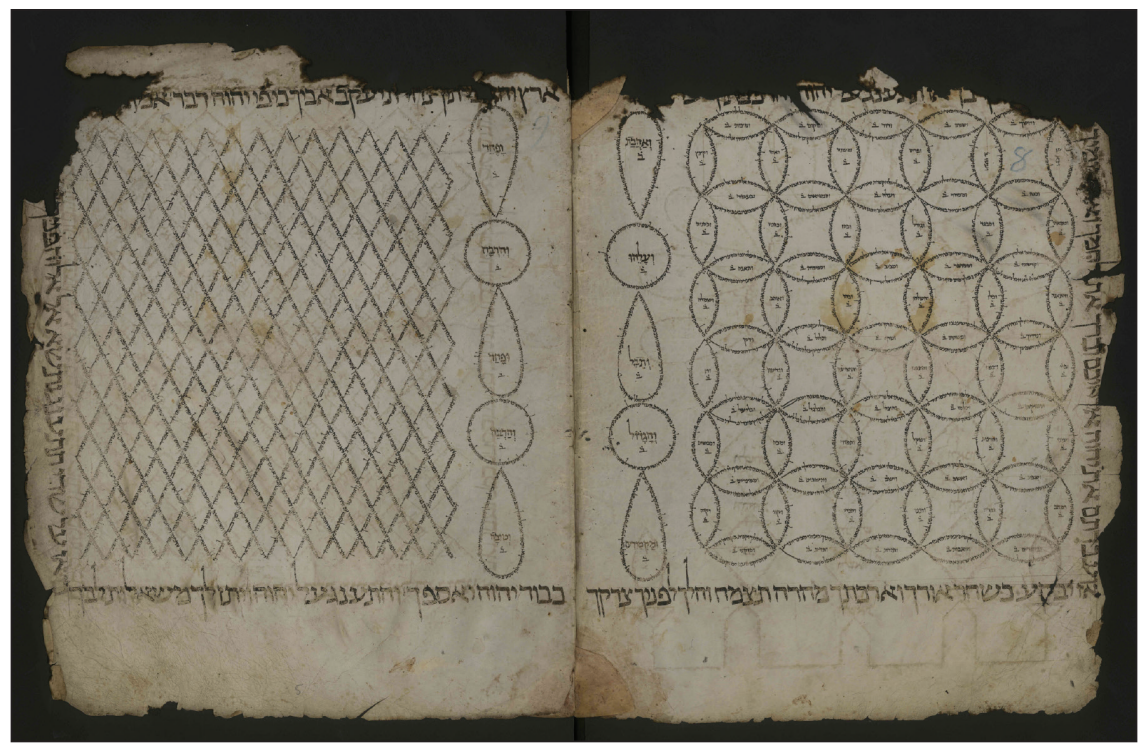

FIGU RE 8. St. Petersburg, National Library of Russia, Evr. II B 1548, fols. 5r/4v, Near Eastern 926-1000. Photograph by permission of the National Library of Russia, Saint Petersburg.

penning creates, for example, as can be seen in National Library of Russia, Evr. II B 1548, folios 4v-5 (fig. 8). This calligraphic frame shows two verses from Isaiah 58. Verse 14 runs across the top line, and Isaiah 58:8 spans most of the bottom line, which is completed with Psalms 37:4. The right side was penned with Exodus 23:25, and Job 22:26 forms the left side of the frame. Naturally, this arrangement precludes any clear understanding of penning sequence or reading flow. That the top and bottom lines were written in sequence either before or after the downward penning of the side lines of the frame suggests a system other than the three found in Iberia. We must consider the possibility that the fact that the writing flow does not span more than one side of the frame is an indication that the scribal convention for creating calligraphic frames did not yet exist. ${ }^{26}$

26 The text could indicate an associative amalgamation of verses calling upon the benedictions that will come to Israel when the people return to God's edicts. The verses are: Isaiah 58:14: "Then shalt thou delight thyself in the LORD, and I will make thee to ride upon the high places of the earth, and I will feed thee with the heritage of Jacob thy father; for the 
As evident, the CCW-CW system was the predominant writing flow in Near Eastern manuscripts, but there are four manuscripts that reflect the CCW and/or CW systems, two of which date to the beginning of the eleventh century, one to the beginning of the twelfth, and another to the thirteenth century. ${ }^{27}$ In National Library of Russia, Evr. I B 19a, six out of the seven calligraphic frames have a CCW-CW flow, and one frame is penned in a continuous line that begins at the bottom left with an "upsidedown" top row. Codex Moshe Ben-Asher (Cairo, Karaite Synagogue, Gottheil 34), assessed paleographically to be from the early eleventh century, includes frames that form a mirrored Catalan system, where the writing begins with the bottom line and then goes from the bottom right up and around to the bottom left. ${ }^{28}$ This can be seen, for example, in the colophon on folio 576r. The clockwise penning in National Library of Russia, Evr. II C 144, Alexandria 1122, is in a continuous line with the top of the frame "upside down." Running clockwise, this continuous writing of the texts is actually a mirrored version of the CCW system and is similar to the inner micrography frame in Castilian and Portuguese manuscripts (see fig. 6). ${ }^{29}$ As in the case of manuscripts from Aragon, these, set almost a century apart from one another, are too distant to be built upon for a developmental

mouth of the LORD hath spoken it"; Isaiah 58:8: "Then shall thy light break forth as the morning, and thy healing shall spring forth speedily; and thy righteousness shall go before thee, the glory of the LORD shall be thy reward"; Psalm 37:4: "So shalt thou delight thyself in the LORD; and He shall give thee the petitions of thy heart"; Exodus 23:25: "And ye shall serve the LORD your God, and He will bless thy bread, and thy water; and I will take sickness away from the midst of thee"; and Job 22:26: "Then surely shalt thou have thy delight in the Almighty, and shalt lift up thy face unto God."

27 The manuscripts are Cairo, Karaite Synagogue, Gottheil 34, Near East, from the early eleventh century along with three manuscripts from the National Library of Russia in St. Petersburg: Evr. I B 19a, Egypt, 1008; Evr. II C 144, Alexandria, 1122; and Evr. II B 168, Tlemsan Tunis, 1225.

28 The colophon of this codex carries the date 894/95 CE, but recent paleographical and codicological assessment dates it to the early eleventh century. Beit-Arié, Sirat, and Glazer, Codices hebraicis litteris exarati quo tempore scripti fuerint exbibentes, 1:28.

29 The penning begins as was more common, at the top right down the right side of the frame, and continues clockwise. 
Halperin: Calligraphic Frames in Sephardic Hebrew Bibles

Halperin, Clockwise-Counterclockwise

conclusion, but they do suggest that this might be a system that developed later.

Finding various writing choreographies for calligraphic frames in this region that conflict reading direction flow and the visual propensity of the frames could be an indication that this scribal art was only in its initial forming stage and had not yet become a tradition. ${ }^{30}$ This possibility suggests that the Near Eastern manuscripts might well have been the cradle for the development of calligraphic frames in Hebrew Bibles. It is possible that these frames developed into a set scribal art form in the twelfth century, at which time the writing flow first correlated with the reading direction, so that they appeared unified. ${ }^{31}$

Attempting to clarify the developmental stages of calligraphic frames requires an examination of Ashkenazi Bible manuscripts as well, especially as the rite they reflect has been shown to be that of the Land of Israel, and this mutuality might have carried over to scribal traits as well. ${ }^{32}$ Calligraphic frames, micrography frames around initial word panels, and images in Ashkenazi manuscripts frequently follow the Near Eastern CCW-CW choreography systems as well as the CCW system. ${ }^{33}$ The Catalan CW system, although "flipped" on its side beginning on the bottom of the right side, can also be found, for example, in the frames of the renowned image of the rampant lion set in a calligraphic frame enclosed by micrographic frames in Vienna, Österreichische Nationalbibliothek, Cod. Heb. 16, folio 226r, circa 1300. However, all of the extant Ashkenazi Bible manuscripts with calligraphic frames date from the late thirteenth century, which precludes the

30 For example, see Cairo, Karaite Synagogue, Gottheil 14.

31 See, e.g., the above-mentioned National Library of Russia, Evr. II C 144, a manuscript from Alexandria, 1122, as well as Evr. II B 168, from Tunis, 1225.

32 Leopold Zunz, Die Gottesdienstlichen Vorträge der Juden, Historisch Entwickelt (Frankfurt am Main, 1892); available at https://reader.digitale-sammlungen.de/de/fs1/object/display/ bsb10570935 00005.html.

33 See, e.g., Sofer Bible (London, Sofer Collection), Germany, 1264; and Berlin, Staatsbibliothek, MS Or. fol. 1211, fol. 7r, Germany, 1300-1350; and Oxford, Bodleian Library, MS Can. Or. 137, fol. 70v. On these manuscripts, see Rahel Fronda, "Attributing Three Ashkenazi Bibles with Micrographic Images,” Ars Judaica 9 (2013): 45-56. 
possibility of any developmental conclusions owing to the vast time gap between the early Near Eastern and the Ashkenazi manuscripts.

\section{Developmental Influences from Surrounding Cultures}

Determining that Near Eastern manuscripts reflect the formative period for this scribal art requires assessing the possible sources of its development. As many micrographic frames surround the final verse counts noted at the end of each biblical book, this scribal feature might be either an internal Jewish scribal art development from the field of micrography or a feature owed to the primary and most influential visual source for the decoration in Hebrew manuscripts-Islamic art. ${ }^{34}$ Both cultures attached enormous importance to the written word, but Islamic manuscripts do not have calligraphic frames. Thus, it is conceivable that an earlier artistic influence can be found on synagogue mosaic floors that include epigraphy, but none of the epigraphic bands on these mosaics form a frame around the floors.

Byzantine icons, devotional artifacts, and manuscript miniatures are known to carry inscribed poetic texts, but these do not form full epigraphic frames around the entire image.

A few of the earliest icons on panels do carry calligraphic complete frames. ${ }^{35}$ One well-known image is the seventh/eighth century Maiestas Domini icon in the Santa Katrina monastery. ${ }^{36}$ Only one manuscript from the mid-tenth century, known as the Leo Sacellarios Bible or Queen Cristina

34 Gutmann, "Masorah Figurata," 51; Halperin, Illuminating in Micrography, 105-10; Kogman-Appel, Jewish Book Art Between Islam and Christianity, 34-50, 54-56, 95-97; SedRajna, "Toledo or Burgos"; Narkiss, Hebrew Illuminated Manuscripts, 28.

35 Ivan Drpić, Epigram, Art, and Devotion in Later Byzantium (Cambridge: Cambridge University Press, 2016), 18-26; Maria Lidova, "L’Icona Acheropita della Vergine di Santa Maria in Trastevere Roma," in Le arti a confronto con il sacro: Metodi di ricerca e nuove prospettive di indagine interdisciplinare. Atti della Giornata di studio (Padova, 31 May-1 June 2007), 25-26. I would like to thank Ivan Drpić for his assistance on Byzantine epigraphic frames.

36 For an image, see Arwed Arnulf, Versus ad Picturas: Studien zur Titulusdichtung als Quellengattung der Kunstgeschichte von der Antike bis zum Hochmittelalter (1997), 321, image 74 . 
Halperin: Calligraphic Frames in Sephardic Hebrew Bibles

Halperin, Clockwise-Counterclockwise

Bible (Biblioteca Apostolica Vaticana, MS Reg. Gr. 1), carries full calligraphic frames, and these, which surround all of the full-page frontispieces, are penned in a CCW-CW system beginning at the top left. ${ }^{37}$ What is fascinating is that the sides of these calligraphic frames are arranged with the vertical part of the frame inscribed with isolated letters or a few letters squeezed together (fig. 9). ${ }^{38}$ This could indicate that at the time the mise en cadre penning system, which was designed to correlate the frame shape visually with the integrity of the writing flow orientation, was not yet in force. The opening pages of the books of the Bible frame the image centered on one biblical event for the Old Testament or one symbolic episode of the New. The forming texts are epigrams written by Leo Sacellarios, a high dignitary of the imperial court and Church. They constitute a poetic exegesis of the biblical text, though not always directly related to it. ${ }^{39}$ Sometimes, there are reciprocal and conceptual ties between these inscriptions and the miniatures' iconography, although, as noted by Mathews, "subtle and oblique" carried to "liturgical ends," and this further complicates their reading. ${ }^{40}$

Apart from a scant few, Latin manuscripts, which are also known to use tituli, do not carry full frames. One example is the ivory back cover of a treasure binding of the eleventh-century Mondsee Gospels from Regensburg, Germany, now held in the Walters Art Museum (MS W. 8). Further, Codex Vyšebradensis, dated to circa 1085, has a miniature with an inscription frame on folio $43 \mathrm{v}^{41}$ There are also calligraphic frames in British Library, Cotton

37 I am indebted to Elisheva Revel-Neher for this reference. On this manuscript, see also T. F. Mathews, "The Epigrams of Leo Sacellarios Bible and an Exegetical Approach to the Miniatures of Vat.Reg.Gr.1," Orientalia Christiana Periodica 43 (1977): 94-133. A devotional ivory diptych of private patronage held in the cathedral treasury of Chambery is also enclosed with epigrams. However, as this artifact is from the later Byzantine era (1100-1450), it is later than the formative period for Hebrew Near Eastern calligraphic frames, so it cannot be used for comparison.

38 On this, see Arnulf, Versus ad Picturas, 324.

39 For the translation of the frames' texts, see Mathews, "The Epigrams of Leo Sacellarios Bible," 127-33.

40 For a translation of the texts of the epigrams in the Leo Sacellarios Bible, see Mathews, “The Epigrams of Leo Sacellarios Bible," 95, 98-99, 109.

41 The miniature depicts the Holy Women at the empty tomb of Christ, but other miniatures are enclosed in decorative frames. 
Manuscript Studies, Vol. 4 [2019], Iss. 2, Art. 2

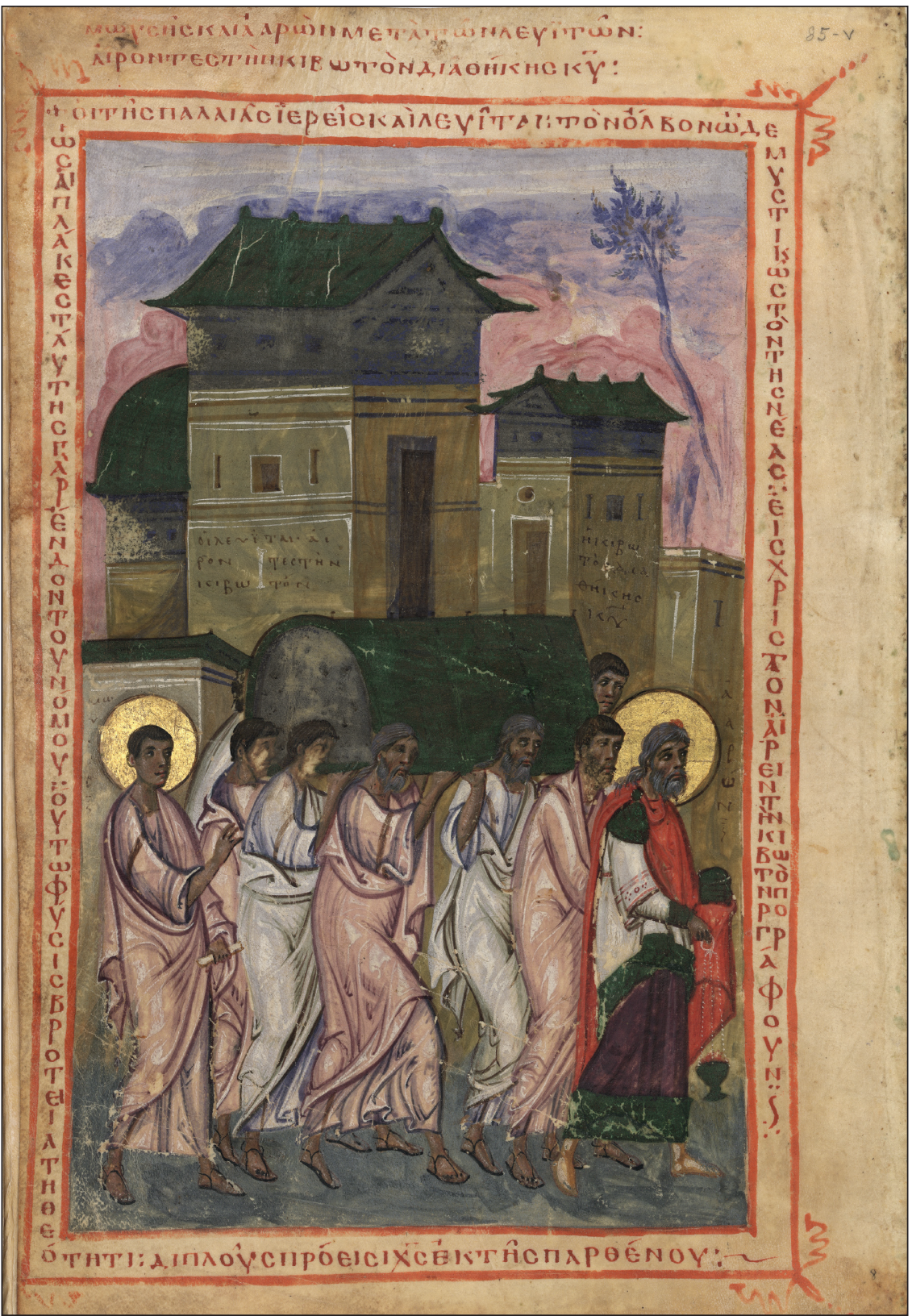

FIGU RE 9. Biblioteca Apostolica Vaticana, MS Reg. Gr. 1, The carrying of the Ark, fol. $85 \mathrm{v}$. Known also as the Leo Sacellarios Bible. Photograph (C) Biblioteca Apostolica Vaticana [2019]. 
MS Caligula A XIV, The Caligula Troper, which is an eleventh-century manuscript from Winchester. The verses that form the frames are penned in different systems with either three sides running CW from either the top right, top left, or bottom left, as, for example, on folios 26r, 26v, and 29r, respectively, or on all four sides with the bottom line topsy-turvy, as on folio $22 r^{42}$ I contend that this mélange of systems in one manuscript indicates a search for the most suitable penning of frames, which suggests that the mise en cadre had not yet been set into a fixed scribal system. The fact that these calligraphic frames did not develop into a Latin scribal art might well highlight the problems of surrounding images with text frames that are not easily read. This was also suggested by Arwed Arnulf, who notes that the orientation of Western inception calligraphic frames differs from that in the Leo Sacellarios Bible in that the letters frame the image so that the bottom of the text touches the interior of the image's frame, as opposed to the down penning in the Leo Sacellarios Bible. This penning requires constant turning of the manuscript in the Latin codex. An inscription frame, although not full, is also found on the Carolingian ivory binding of the Ivory diptych from Genoels-Elderen (Brussels, Musées royaux d'Art et d'Histoire), which dates to the ninth century. Whereas one of the covers carries an incomplete frame, the other has only horizontal strips of writing set within it. The miniatures in this manuscript are surrounded solely by decorative frames. Arnulf stresses that textual frames were adopted from Byzantine works such as in the Regensburg manuscript, which thus may reflect a Byzantine influence, especially as such frames were unknown in the early Christian and Carolingian West. ${ }^{43}$ This Byzantine influence on Carolingian art brings us back to the Leo Sacellarios Bible.

Although the date ascribed to the Leo Sacellarios Bible coincides with the frames of Near Eastern manuscripts, and icons such as the Maiestas Domini in the Santa Katrina monastery are even earlier, can we suggest a Byzantine

42 Images can be accessed at the British Library site: http://www.bl.uk/manuscripts/Viewer. aspx?ref=cotton_ms_caligula_a_xiv_f001r (accessed 18 August 2018).

43 Arnulf, "The Epigrams of Leo Sacellarios Bible," 324-25. On Byzantine influence by travelers, see also Krijna Nelly Ciggaar, Western Travellers to Constantinople: The West and Byzantium, 962-1204 (Leiden: Brill, 1996), 133-37, 325. 
influence on Hebrew Near Eastern Bibles? I suggest that although it may seem a possible artistic venue of influence, the writings against Christianity by Jewish sages, who held it to be an idolatrous religion, demand we seek such influential artistic roots elsewhere. ${ }^{44}$

This brings us back to Islamic manuscripts. As I noted above, although Islamic manuscripts do not carry epigraphic frames, Islamic architecture does have them. The earliest such epigraphic band is the running inscription on the outer face of the octagonal arcade of the Dome of the Rock in Jerusalem (688-91), which predates the utilization of epigraphic frames in Near Eastern Hebrew Bibles (fig. 10). ${ }^{45}$

In his book The Dome of the Rock and Its Umayyad Mosaic Inscriptions, Marcus Milwright suggests that the epigraphic bands around the cornices of churches known from the fifth century as well as those on small portable objects could have been the model for the use of Umayyad inscriptions. ${ }^{46}$ As churches and Friday mosques (Jama Masjid) in Umayyad cities were built in close proximity to one another, these epigraphic bands might easily have been appropriated into Umayyad mosque architecture and later have been readily available as replacements for the decorative bands that surrounded the early mihrabs. ${ }^{47}$ Most importantly, Milwright contends that the entire

44 Babylonian Talmud, Tractate Avoda Zara 7:2, recounts Sunday as an idol worshippers' festive day. This was a major source on which Maimonides determined Christianity to be an idolatrous religion. See Maimonides, Commentary on the Mishnah, Avodab Zarah, 1:3, 1:4. RaSaG (Rabbi Saadia Gaon (882-942), one of the last Geonim, also viewed Christians as idolaters. See Eliezer Schlosberg, "RaSaG's Attitude Towards the Islam," DAAT 25 (1990): 22n10. I would like to thank Nahem Ilan, head of the School of Jewish Studies at the Ono Academic College, for this reference.

45 On the Dome of the Rock inscriptions, see Oleg Grabar, Shape of the Holy: Early Islamic Jerusalem (Princeton, NJ: Princeton University Press, 1996), 56-71; Marcus Milwright, The Dome of the Rock and Its Umayyad Inscriptions (Edinburgh: Edinburgh University Press, 2016); and Sheila Blair, "What Is the Date of the Dome of the Rock," in Bayt-al-Maqdis 'Abd al-Malik's Jerusalem (Oxford: Oxford University Press, 1992), 1:59-87.

46 Milwright, The Dome of the Rock and Its Umayyad Inscriptions, 88. These inscriptions became rare as of the late seventh century. Grabar, Islam and Muslim Art, 71.

47 Jama Masjid, or "congregational mosque," is conflated with the word for Friday, the primary day of worship in Islam. On the influence of the definition of the sacred space of church architecture on that of Friday mosques, see Mattia Guidetti, "The Contiguity Between Churches and Mosques in Early Islamic Bilad al-Saham," Bulletin of SOAS [School of Oriental 
Halperin: Calligraphic Frames in Sephardic Hebrew Bibles

Halperin, Clockwise-Counterclockwise

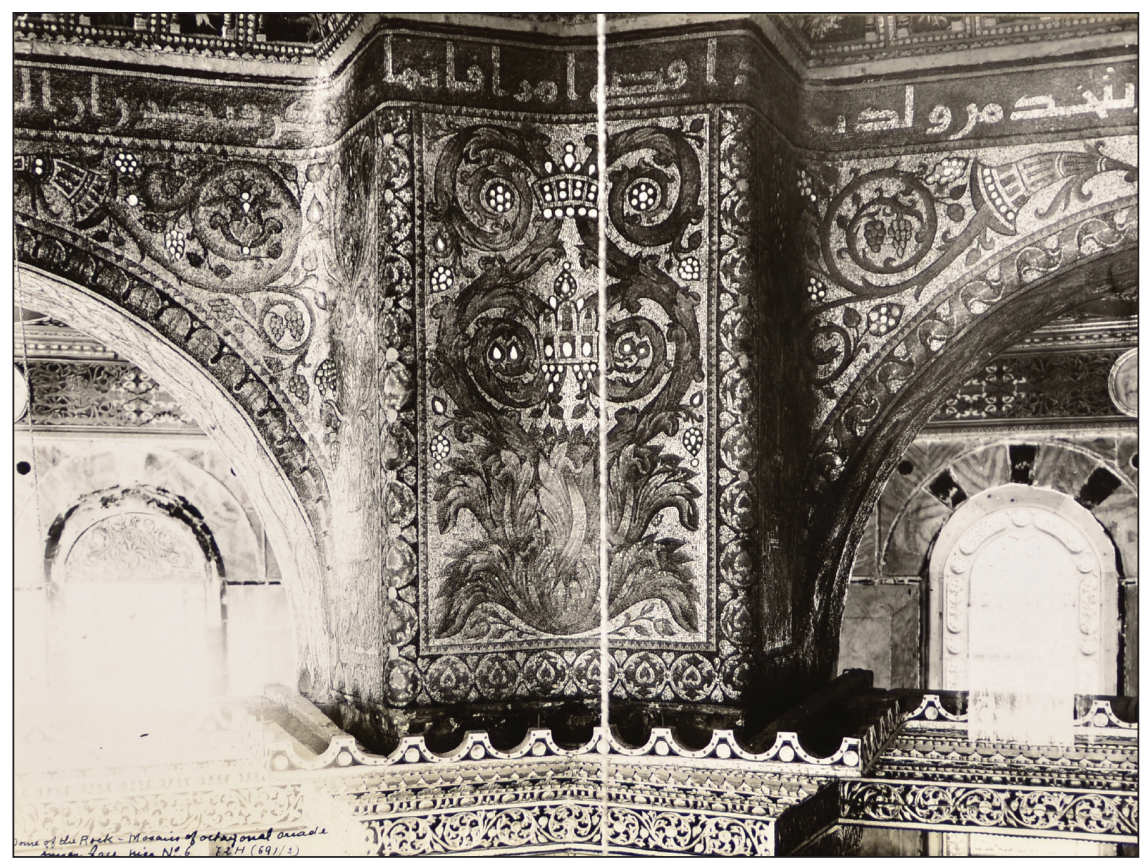

FIGURE 10. Dome of the Rock, detail of the outer face of the octagonal arcade, Jerusalem 688-91. British Mandate Archive. Courtesy of the Israel Antiquities Authority.

inscription on the Dome of the Rock shows signs of experimentation, which would lend support to the notion that this was a formative developmental period for Islamic architectural frames. ${ }^{48}$ Some of the most renowned inscriptions include those on the mihrab of Nain (tenth century), the Great Mosque in Córdoba (965), and the Mosque of Ibn Tulun (1094). ${ }^{49}$ These

and African Studies] 76, no. 2 (2013): 229-58. The portal niche is symbolic of the Temple's Holy of Holies indicating the direction of the city of Mecca. For more information, see The Grove Encyclopedia of Islamic Art and Arch, ed. Jonathan Bloom and Sheila Blair (Oxford: Oxford University Press, 2009), 2:515-17, s.v. "Mihrab."

48 Milwright, The Dome of the Rock and Its Umayyad Inscriptions, 156-57.

49 Adolf Grohmann, "The Origin and Early Development of Floriated Kufic," in Ars Orientalis, vol. 2 (Washington, DC: Freer Gallery of Art, 1957), 188, 194-95, 203-9, 212-13; Richard Ettinghausen and Oleg Grabar, The Art and Architecture of Islam, 650-1250 (New Haven: Yale University Press, 1987), 119; Markus Hattestein and Peter Delius, eds., Islam: Art and Architecture (Cologne: H. Fulmann, 2000), 626. 
bands surround the mihrabs on three sides, beginning at the bottom right and running in a continuous band that is in accord with the flow of Arabic script from right to left. When such inscriptions appear around mosque windows, the bottom line added to close the square is also penned right to left. These window frames reflect a Catalan CW penning, but one in a vertical flipped mirror of this system.

The texts used to form Islamic epigraphy are taken from the Qur'an and carry messages of faith and devotion. ${ }^{50}$ These inscriptions are designed so that the viewer can actually read them. ${ }^{51}$ In this context, Nuha Khoury explains how the inscriptions in the Great Mosque of Cordoba (961-96) function to identify the structure as a representation of a mythical and historical caliphate on earth. The verses also reflect God's omnipotence and omniscience, indicating that prayer is the way to fulfill religious obligations. ${ }^{52}$ An Islamic influence on Near Eastern Hebrew manuscripts manifested in the decorative motifs and architectural elements typical of Islamic architecture that are found on carpet pages of these Bibles attest to this cultural influence. The similar content of the epigraphic inscriptions of the two cultures further supports the notion that Islamic art also had a formative influence of on the texts used for Hebrew manuscript decoration.

As noted above, Near Eastern Hebrew manuscripts reflect a search for penning and readability when forming the calligraphic frames because of the conflict between reading and the mise en cadre flows. As Islamic art is known to have been an important influence on the decorative language of

50 Grabar, Islam and Muslim Art, 62-71; Blair, "What Is the Date of the Dome of the Rock," 70-77; Rahel Milstein, "Hebrew Book Illumination in the Fatamid Era," in L'Egypte Fatamide son art et son bistoire, ed. Marianne Barrucand (Paris: Presses de l'Université de Paris-Sorbonne, 1999), 429-40. I would also like to thank Rahel Milstein for her assistance in regard to early Islamic architecture structures and their inscriptions.

51 Nasiba Baimatowa, "The Composition of Kufi Inscription in Transitional and EarlyIslamic Architecture of North Khurasan,” in Mohammad Gharipour and Irvin Cemil Schick (eds.), Calligraphy and Architecture in the Muslim World (Edinburgh: Edinburgh University Press, 2013), 388; Erica Cruikshank Dodd and Shereen Khairallah (eds.), The Image of the Word: A Study of Quranic Verses in Islamic Architecture (Beirut: American University of Beirut, 1981), 24-25.

52 Nuha Khoury, "The Meaning of the Great Mosque of Cordoba in the Tenth Century," Muqarnas 13 (1996): 86-88. 
Halperin: Calligraphic Frames in Sephardic Hebrew Bibles

Halperin, Clockwise-Counterclockwise

these manuscripts, Islamic epigraphic bands should also be considered as sources for the development of calligraphic frames.

The visual orientation of the text is not the only similarity between the Islamic and Jewish Near Eastern calligraphic frames. Although forming text that reflects a religious content is evident in manuscripts from all three monotheistic cultures, both Islamic and Hebrew inscriptions carry messages of faith. ${ }^{53}$ These are evident from those on the Dome of the Rock and the ones that surround mihrabs. ${ }^{54}$ The inscription over some mihrabs is the Qur'anic passage (xix.11), "then he [Zakariya] came forth to his people from the sanctuary/place of worship." The messianic hope of redemption and the rebuilding of the Temple is paramount in Hebrew Bible calligraphic frames. For Islam, God's "picture" is revealed through The Word, so the use of Quranic texts became the representation of God. ${ }^{55}$

I suggest that scribes appropriated this idea from the three-dimensional mosque structure with its epigrams of faith and set it into a two-dimensional temple — miqdasya - with its carpet page separations functioning in the same way as the Temple's curtained separations. ${ }^{56}$ The carpet pages, along with

53 Dalia-Ruth Halperin, "Micrography," in The Encyclopedia of Jewish Book Cultures, ed. Emile Schrijver, Katrin Kogman-Appel, Judith Olszowy-Schlanger, and Aviad Stollman (Leiden: Brill, forthcoming). See also above n. 53.

54 Milstein, "Hebrew Book Illumination in the Fatamid Era," 439; Alexandre Papadopoulo, Islam and Muslim Art (New York: Harry N. Abrams, 1979), 226-27; Grabar, Islam and Muslim Art, 62-71.

55 The question of the use of images came up simultaneously in the eighth century in both Islam and Christianity. However, whereas in Christianity the iconodules triumphed and images were reintroduced in Byzantine art, Islam utilized Quranic texts as “images." See Dodd and Khairallah, The Image of the Word; Annemarie Schimmel, Islamic Calligraphy (Leiden: Brill, 1970), introduction.

56 As the twenty-four books of Scripture are arranged in a threefold division (Pentateuch, Prophets, and Hagiography), and Near East and Iberian cultures saw that as a reflection of the threefold division in the Temple (Antechamber: ulam, Holy: heichal/kodesh, and Holy of Holies: kodesh kodashim), Bible manuscripts in these two regions are called miqdash-ya (God's Temple). Moreover, as many Hebrew and Aramaic words related to architecture are used to define various sections of the codex, such as sh'aar (gate), 'amud (column), baba (Aramaic: gate), tur (Aramaic: column), etc., and as Scripture was named miqdashya in these Oriental and Spanish Bibles, it is possible to see allusions to the Temple in the decorative architectural elements in these manuscripts. See Avrin, "The Illuminations in the Moshe Ben-Asher Codex 
their enclosing epigrams, function as symbolic portals of faith similar to the function of Islamic mihrabs. ${ }^{57}$

To understand how this borrowing might have occurred, we must remember that Islam, as opposed to Christianity, was not considered an idolatrous religion, so entering a mosque was not forbidden. ${ }^{58}$ Moreover, as is evident from countless documents written in Arabic or Judeo-Arabic (Arabic in Hebrew script), Jewish communities under Islamic rule spoke Arabic.

I suggest that a Jew entering a mosque would easily notice the epigraphic bands around the mihrab and cornices and understand their content of faith and devotion. As noted by Dan Pagis, this could well have engendered the tendency for Jewish scribes to appropriate the content of epigraphic bands for their own needs, enveloping carpet pages alluding to the threefold division of the Temple with verses of faith. ${ }^{59}$

\section{Mise en cadre and Its Relation to Forming Text}

But how does one convey an epigraphy set on a three-dimensional architectural form onto a two-dimensional manuscript page?

I suggest that this is precisely the reason that we find various methods of penning frames in Hebrew Near Eastern manuscripts. I consider it an indication that the scribes were searching for a way to render script flow and readability congruent. Setting the three-dimensional square of architectural epigraphy onto the two-dimensional page in a manuscript would lead to the continuous running CCW script. However, as this system creates a flipped line requiring one to turn the manuscript in order to read the frame's

of 895 CE," 184-86; Leila Avrin, "Note on Micrography: A Jewish Art Form," Journal of Jewish Art 6 (1979): 114; Gutmann, Hebrew Manuscript Painting, 18; Gutmann, "The Messianic Temple," 172; J. N. Hillgarth and B. Narkiss, "A List of Hebrew Books (1330) and a Contract to Illuminated Manuscripts (11350) from Majorca,” Revue des etudes Juives 3 (1961): 319; Narkiss, Hebrew Illuminated Manuscripts, 29, 69; and Milstein, "Hebrew Book Illumination in the Fatamid Era," 431-32.

57 Papadopoulo, Islam and Muslim Art, 227.

58 Schlosberg, "RaSaG's Attitude Towards the Islam," 33-35.

59 Dan Pagis, Poetry Aptly Explained (Jerusalem: Magnes Press, 1993), 90. 
text, it hinders readability. The other choice, the CCW-CW system, might have improved readability as the side lines are penned downward, a feature that offers easier reading than if they were to run upward. ${ }^{60}$ However, I consider that the most "reader-friendly" approach is the CW system, which begins as the Hebrew script penning from right to left on the top line and completes the square with a continuous line running from the top right downward to the top left. I suggest that these considerations were at the basis of the search for a system in Hebrew Near Eastern manuscripts.

The immense influence of the Islamic Iberian Peninsula on Jewish and Latin art is also evident in the use of Islamic motifs such as the foliate palmette scroll as well as in the superiority and supersession of the Andalusian Sephardic script over the scripts in Catalonia and Provence, which bear similarities to Ashkenazi scripts. ${ }^{61}$ The clear regional developments should be considered against the content of these frames.

I suggest that the Iberian Peninsula preference for beginning the penning of calligraphic frames at the top right is partially based on the need for visual clarity. Artistically, the topsy-turvy top line found in Near Eastern calligraphic inscriptions visually weighs down on the frame and is a logical starting point for architectural elements, as it gives weight to the form and facilitates reading. Set on a page, however, this heaviness actually weighs down on the text space proportionality and detracts from the folio's aesthetic quality of airiness that characterizes the golden section proportions of the text-to-margin ratio in medieval manuscripts. ${ }^{62}$ Reversing the frame's

60 Titles on bindings even to this day generally run downward.

61 From the end of the eleventh century, an evolutionary but swift change was seen toward a preference for Andalusian Sephardic script, and by the mid-twelfth century that had become the characteristic script of these regions as well. See Malachi Beit-Arié and Edna Engel, Specimens of Mediaeval Hebrew Scripts, vol. 2: Sefardic Script (Jerusalem: Israeli Academy of Sciences, 2002), 12-13; Malachi Beit-Arié, "Hebrew Script in Spain: Development, Offshoots and Vicissitudes," in Beinart, Moreshet Sepharad, 287-88, 290-91; Edna Engel, "Hebrew Scripts in Medieval Catalonia," Actes del I congrés per a l'estudi dels Jueus en territori dee llengua Catalana, Barcelona-Girona Del 15 al 17 d'octubre de 2001 (Barcelona: Universitat de Barcelona, Publicacions i Edicions, 2004), 121, 126-27, and 137 diagram 12.

62 Jan Tschichold, The Form of the Book: Essays on the Morality of Good Design, trans. Hajo Hadeler; introduction by Robert Bringhurst (Point Roberts, WA: Hartley \& Marks, 1991), 37-44. 
topsy-turvy line to the bottom, as in the Castilian tradition, moved the visually weighty part to its "proper" visual point-the bottom-thus creating a lighter visual effect on the page as a whole. Sheila Blair indicates a similar concern in Islamic manuscripts in which embellished letters, interlace, and plant motifs served as devices to add weight to the upper part of the page so as to counter the weightiness of the lower line. ${ }^{63}$

The dismissal of the CCW-CW system in Hebrew manuscripts is baffling, however, as its penning does away with a topsy-turvy line that is difficult to read, as indicated in the system described above. Penning the frame in half-sections organized and facilitated the reading, which suggests that scribes indeed considered reading calligraphic frames with top-down penning so the side of the frame could be read more easily than in a bottomupward flow.

The Catalan system, which rejected the upside-down text line evident in Islamic inscriptions surrounding windows, seems to have maintained an emphasis on the readability of the early Near Eastern CCW-CW choreography. The reversal of the system to begin at the top right and not the bottom right would also reflect a scribal concern with the sense of the page's weightiness. Since both readability and coherence were important in Near Eastern manuscripts, why did this system go out of favor? I suggest that the answer lies in the content of these frames.

It has been argued that carpet pages, which are usually set between the three major textual divisions of Hebrew Bibles-Pentateuch, Prophets, and Hagiography-function not only as decorative elements but also create a visual bracketing system that draws a thematic analogy to the three divisions of the Sanctuary and Temple. This was further emphasized by the Bible being called miqdasbya, God's Temple, in both Near Eastern and Iberian Hebrew Bible manuscripts. ${ }^{64}$ The extensive research primarily on

63 Sheila Blair, "Legibility Versus Decoration in Islamic Epigraphy: The Case of Interlacing," in Themes of Unity in Diversity: Acts of the XXVIth International Congress of the History of Art, ed. Irving Lavin (University Park: Pennsylvania State University, 1990), 2:229.

64 This decoration component is usually spread across the opening of the first segment of the manuscript. See Avrin, "The Illuminations in the Moshe Ben-Asher Codex of 895 CE," 184-86; Gutmann, Hebrew Manuscript Painting, 18; Milstein, "Hebrew Book Illumination in 
Halperin: Calligraphic Frames in Sephardic Hebrew Bibles

Halperin, Clockwise-Counterclockwise

Catalan manuscripts indicates that this unique Sephardic manuscript decoration of Temple Implement pages reveals a reciprocal relationship between the forming text of the frames that surround these pages and the miniatures themselves. The Catalan Bible frame texts are formed of biblical verses that address matters of faith and also carry an eschatological significance that expresses the expectation of redemption and the construction of the Third Temple.

The forming texts in Castilian Bible calligraphic frames differ in content from those of Catalonia. ${ }^{65}$ In manuscripts from Castile and Portugal as well as in some from Aragon, the calligraphic frames comprised largely Masoretic lists and to a lesser extent words of praise for the Torah as the source of wisdom and truth. For example, in the Toledo Bible (see fig. 1) the verses forming the calligraphic frames surrounding the Temple Implement pages are formed by Proverbs 2:3-11 and 3:1-3 and on folios $3 \mathrm{v}-5 \mathrm{v}$ by Proverbs 8-9. Words of praise for the Torah as the source of wisdom and truth are

the Fatamid Era," 432; Bezalel Narkiss, Hebrew Illuminated Manuscripts, 25; and Halperin, Illuminating in Micrography, 14. Regarding the text, see Dan Barag, "The Menorah as a Messianic Symbol," in The Light of the Menorab: Story of a Symbol, ed. Yael Israeli (Jerusalem: Israel Museum, 1999), 71-76; Gutmann, "The Messianic Temple," 125-45; Halperin, Illuminating in Micrography, 92-105; Kogman-Appel, Jewish Book Art Between Islam and Christianity, 68-88, 131-68; Thérèse Metzger, "Les Objects du culte, le Sanctuaire du Désert et le Temple de Jérusalem dans les Bibles Hébraïques enluminées, en Orient et en Espagne," Bulletin of the John Rylands Library 52 (1969): 397-437; 53 (1970-71): 169-85; Elisheva Revel-Neher, Le Témoignage de l'Absence: les objets du sanctuaire à Byzance et dans l'art Juif du $X I_{\underline{e}}^{e}$ an $X V_{\underline{e}}^{e}$ siècles (Paris: De Boccard, 1998), 64-83; Gabrielle Sed-Rajna, "Images of the Tabernacle/Temple in Late Antique and Medieval Art: The State of Research" (The Real and Ideal Jerusalem in Jewish, Christian and Muslim Art), Jewish Art 23/24 (1997/1998): 42-53. 65 On the Castilian practice, see Kogman-Appel, Jewish Book Art Between Islam and Christianity, 138-39, 141-42. See also Gutmann, Hebrew Manuscript Painting, 18-19, 50; Narkiss, Hebrew Illuminated Manuscripts, 28; Revel-Neher, Le Témoignage de l'Absence, 69; Elisheva Revel-Neher, "An Additional Key to the Program of the Dura-Europos Synagogue Frescoes: Ezekiel 37," in And Let Them Make Me a Sanctuary: Synagogues from Ancient Times to the Present Day, ed. Y. Eshel, E. Netzer, D. Amit, and D. Cassuto (Ariel: Ariel University Press, 2004), 67-75; Kogman-Appel, Jewish Book Art Between Islam and Christianity, 141-42; and Eva Frojmovic, "Messianic Politics in Re-Christianized Spain: Images of the Sanctuary in Hebrew Bible Manuscripts," Imagining the Self, Imagining the Other: Visual Representation and Jewish-Christian Dynamics in the Middle Ages and Early Modern Period, ed. Eva Frojmovic (Leiden: Brill, 2002), 98-106, 108-9. 
also found in Ibn Gaon's manuscripts, which are attributed to northern Castile/Navarre, as in Paris, Bibliothèque nationale de France, MS Hébreu 21, fol. 4v, penned with Deuteronomy 6:24-25, but the frame on folio $117 \mathrm{v}$ is formed with Masoretic texts.

Reevaluating Haverford College, Rendel Harris 1 reveals that its "Catalan" and "northern Castile/Navarre" frames are formed from Masoretic texts, which would strengthen the notion of its Navarrese or even northern Castilian origin. ${ }^{66}$

Catalan manuscripts are clearly distinguishable from those from the rest of the Iberian Peninsula in both the content of the forming text and its writing flow. One must then ask whether the use of a lexical text such as the Masorah would indicate that there was no conceptual or reciprocal association between text and image in the Castilian manuscripts.

As we read in Tractate Avot 3:13 regarding the masorab (the tradition passed on): "Tradition is a fence around the Torah" (מסורת סייג לתורה). This may mirror the task of Masorah to safeguard the biblical text from changes. Thus, we might consider the formation of calligraphic frames along the lines suggested by David Stern for Masorah figurata: a conceptual fence of faith and safekeeping. ${ }^{67}$

Readability was important to the Castilian scribe just as it was to those in northern Castile/Navarre and Catalan, whose penning system, as shown, facilitated the reading and readability of the frames formed solely from biblical verses and segments of prayers. In Castile, the Masoretic content of the frames may have led to some disregard for easy readership in favor of maintaining coherent uncorrupted Masoretic text, as any break in that text could easily lead to confusion and later corruption, so ensuring a coherent reading was essential.

The scribal traditions evident in these calligraphic frames, which were set by the thirteenth century, and the way in which they developed can be considered indicative of their particular regional settings. These frames along

66 Some of its decorative elements would seem to draw from the Hebrew Castilian Bible decoration.

67 David Stern, "The First Jewish Books and the Early History of Jewish Reading," Jewish Quarterly Review 98, no. 2 (2008): 189; Halperin, Illuminating in Micrography, 18n58, 21. 
Halperin: Calligraphic Frames in Sephardic Hebrew Bibles

with other codicological and artistic factors may help us ascribe manuscripts to their respective milieus. Most importantly, these considerations allow for an understanding of each region's literary and scholarly interests and its specific emphases on readability, its cross-cultural and cross-regional influences, and a better understanding of the interactions among the various communities. 
Manuscript Studies, Vol. 4 [2019], Iss. 2, Art. 2

\section{Appendix: Manuscripts in Chronological Order}

\begin{tabular}{|c|c|c|c|c|c|c|}
\hline & Shelf mark & $\begin{array}{l}\text { Reading } \\
\text { flow not } \\
\text { deter- } \\
\text { minable }\end{array}$ & $\begin{array}{l}\text { Counter- } \\
\text { clockwise } \\
\square \hat{}\end{array}$ & Clockwise & $\begin{array}{l}\text { Counter- } \\
\text { clockwise- } \\
\text { Clockwise } \\
\end{array}$ & Region \\
\hline 1 & $\begin{array}{l}\text { St. Petersburg, } \\
\text { National Library of } \\
\text { Russia, Evr. II B 17, } \\
\text { Near East, } 929\end{array}$ & $* *$ & & & $\begin{array}{l}* * \text { [visually } \\
\text { only] }\end{array}$ & Eastern \\
\hline 2 & $\begin{array}{l}\text { St. Petersburg, } \\
\text { National Library of } \\
\text { Russia, Evr. II B } \\
\text { 1548, Near East, } \\
926-1000\end{array}$ & & & & $* *$ & Eastern \\
\hline 3 & $\begin{array}{l}\text { Cairo, Karaite } \\
\text { Synagogue, Gottheil } \\
\text { 14, Egypt, ca. } 1000\end{array}$ & & ** (1of 4) & $\begin{array}{l}* *[1 \text { of } 4 \\
\text { visually } \\
\text { only] }\end{array}$ & & Eastern \\
\hline 4 & $\begin{array}{l}\text { St. Petersburg, } \\
\text { National Library of } \\
\text { Russia, Evr. I B 19a, } \\
\text { Egypt, } 1008\end{array}$ & $* *$ & ** $(1$ of 7$)$ & & $\begin{array}{l}* * \text { [visually } \\
\text { only] }\end{array}$ & Eastern \\
\hline 5 & $\begin{array}{l}\text { Cairo, Karaite } \\
\text { Synagogue, Gottheil } \\
\text { 34, Near East (895), } \\
\text { ca. early 11th century }\end{array}$ & & $\begin{array}{l}\text { ** [reading } \\
\text { flow] }\end{array}$ & & $\begin{array}{l}{ }^{* *} \text { [visually } \\
\text { only] }\end{array}$ & Eastern \\
\hline 6 & $\begin{array}{l}\text { St. Petersburg, } \\
\text { National Library of } \\
\text { Russia, Evr. II B 269, } \\
\text { Near East, } 1075\end{array}$ & $* *$ & & & $\begin{array}{l}\text { ** [visually } \\
\text { only] }\end{array}$ & Eastern \\
\hline 7 & $\begin{array}{l}\text { St. Petersburg, } \\
\text { National Library of } \\
\text { Russia, Evr. II C 144, } \\
\text { Alexandria, } 1122\end{array}$ & & $* *$ & & & Eastern \\
\hline 8 & $\begin{array}{l}\text { St. Petersburg, } \\
\text { National Library of } \\
\text { Russia, Evr. II B 168, } \\
\text { Tlemcen/Tunis, } 1225\end{array}$ & & & & $* *$ & Eastern \\
\hline
\end{tabular}


Halperin: Calligraphic Frames in Sephardic Hebrew Bibles

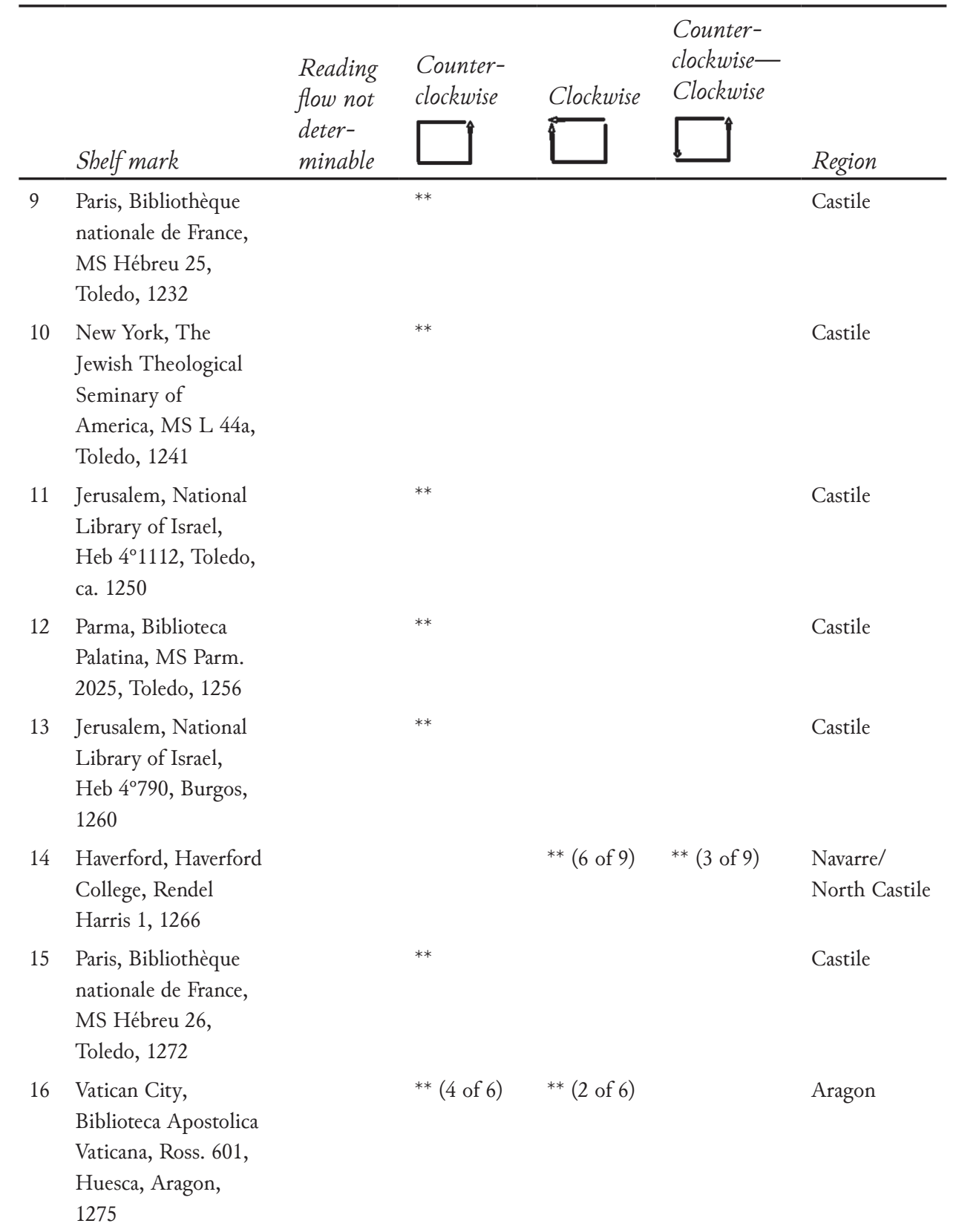


Manuscript Studies, Vol. 4 [2019], Iss. 2, Art. 2

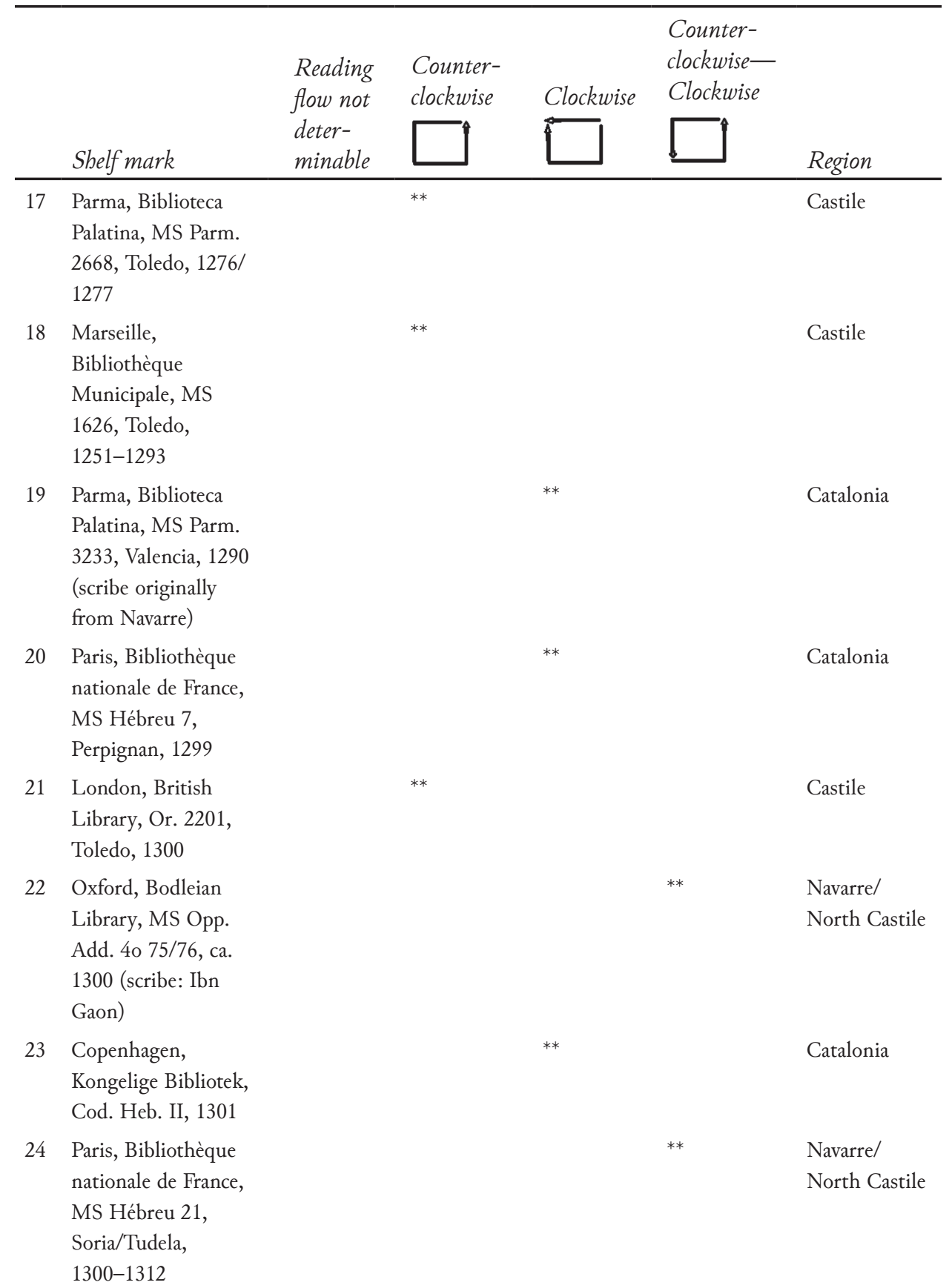


Halperin: Calligraphic Frames in Sephardic Hebrew Bibles

\begin{tabular}{|c|c|c|c|c|c|c|}
\hline & Shelf mark & $\begin{array}{l}\text { Reading } \\
\text { flow not } \\
\text { deter- } \\
\text { minable }\end{array}$ & $\begin{array}{l}\text { Counter- } \\
\text { clockwise }\end{array}$ & Clockwise & $\begin{array}{l}\text { Counter- } \\
\text { clockwise- } \\
\text { Clockwise } \\
\square\end{array}$ & Region \\
\hline 25 & $\begin{array}{l}\text { Oxford, Bodleian } \\
\text { Library, MS } \\
\text { Kennicott 2, Soria/ } \\
\text { Tudela, } 1306\end{array}$ & & & & $* *$ & $\begin{array}{l}\text { Navarre/ } \\
\text { North Castile }\end{array}$ \\
\hline 26 & $\begin{array}{l}\text { Letchworth, Sassoon } \\
\text { Collection, MS 508, } \\
\text { Toledo, } 1307\end{array}$ & & $* *$ & & & Castile \\
\hline 27 & $\begin{array}{l}\text { Rome, Biblioteca } \\
\text { della Comunità } \\
\text { Israelitica, MS 3, } \\
\text { Barcelona, } 1325\end{array}$ & & & $* *$ & & Catalonia \\
\hline 28 & $\begin{array}{l}\text { Letchworth, Sassoon } \\
\text { Collection, MS } 368 \text {, } \\
\text { Provence, } 1366-82\end{array}$ & & & $* *$ & & Catalonia \\
\hline 29 & $\begin{array}{l}\text { London, British } \\
\text { Library, Kings MS 1, } \\
\text { Solsona, } 1383\end{array}$ & & ** (2 of 12$)$ & $* *$ & & Catalonia \\
\hline 30 & $\begin{array}{l}\text { London, British } \\
\text { Library, Harley MS } \\
\text { 5774-5775, Castelló } \\
\text { d'Empúries, } 1396\end{array}$ & & & $* *$ & & Catalonia \\
\hline 31 & $\begin{array}{l}\text { Paris, Bibliothèque } \\
\text { nationale de France, } \\
\text { MS Hébreu 31, } \\
\text { Saragossa, } 1404\end{array}$ & & $* *$ & & & Aragon \\
\hline 32 & $\begin{array}{l}\text { Cambridge, Trinity } \\
\text { College, F. } 12.70-71 \text {, } \\
\text { Avignon } 1419\end{array}$ & & & $* *$ & & Catalonia \\
\hline 33 & $\begin{array}{l}\text { Modena, Biblioteca } \\
\text { Estense, MS a.0.5.9, } \\
\text { Seville, } 1470\end{array}$ & & $* *$ & & & Castile \\
\hline 34 & $\begin{array}{l}\text { Oxford, Bodleian } \\
\text { Library, MS Can. } \\
\text { Or. 42, Mora, } \\
\text { Portugal, } 1470\end{array}$ & & $* *$ & & & Portugal \\
\hline
\end{tabular}


Manuscript Studies, Vol. 4 [2019], Iss. 2, Art. 2

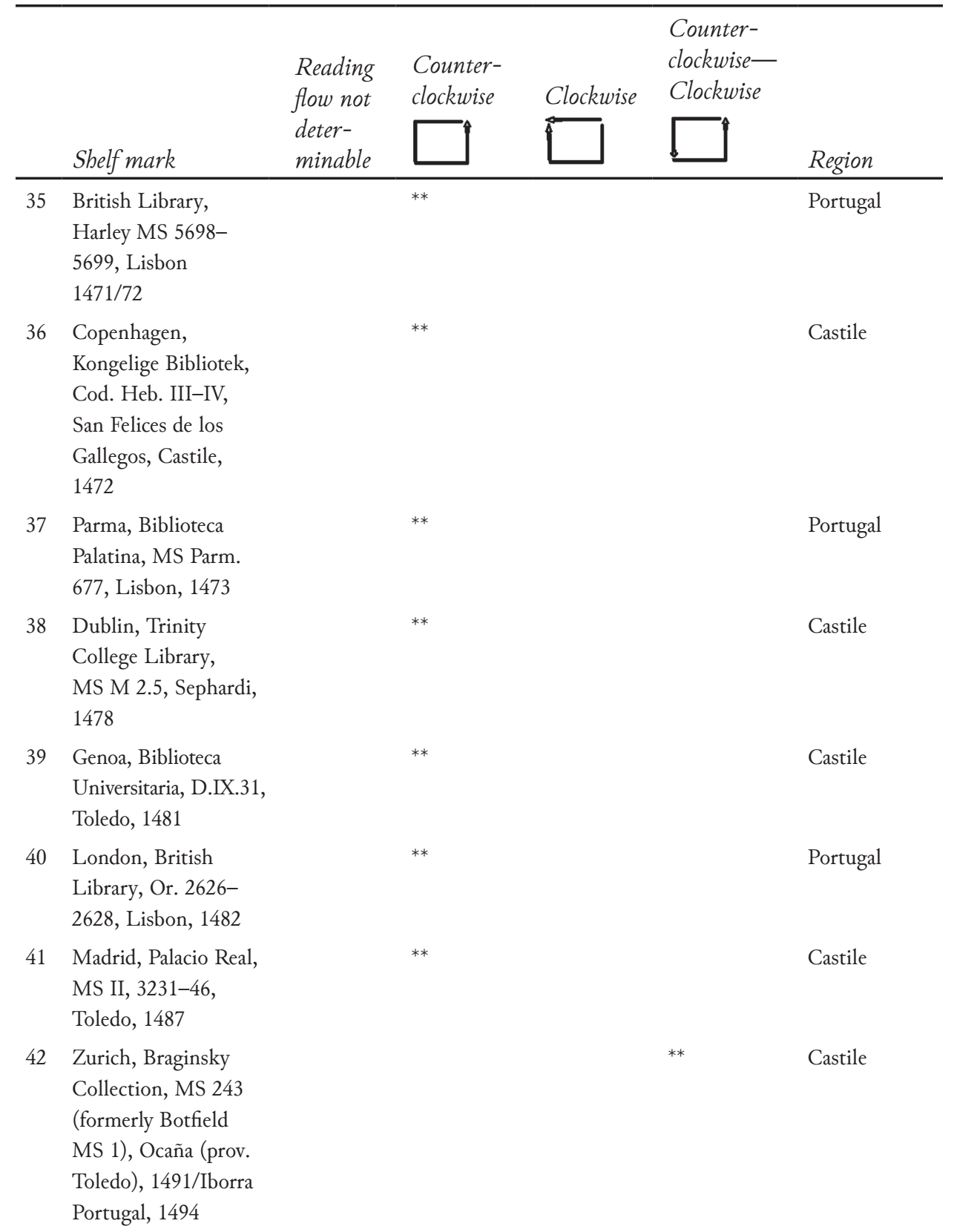


Halperin: Calligraphic Frames in Sephardic Hebrew Bibles

\begin{tabular}{|c|c|c|c|c|c|c|}
\hline & Shelf mark & $\begin{array}{l}\text { Reading } \\
\text { flow not } \\
\text { deter- } \\
\text { minable }\end{array}$ & $\begin{array}{l}\text { Counter- } \\
\text { clockwise } \\
\square\end{array}$ & Clockwise & $\begin{array}{l}\text { Counter- } \\
\text { clockwise- } \\
\text { Clockwise } \\
\end{array}$ & Region \\
\hline 43 & $\begin{array}{l}\text { New York, The } \\
\text { Jewish Theological } \\
\text { Seminary of } \\
\text { America, MS L.6, } \\
\text { Toledo, } 1492\end{array}$ & & $* *$ & & & Castile \\
\hline 44 & $\begin{array}{l}\text { Philadelphia, Free } \\
\text { Library, Lewis O } \\
\text { 140, Lisbon, } 1496\end{array}$ & & $* *$ & & ** $(1$ of 20$)$ & Portugal \\
\hline
\end{tabular}




\section{List OF MANUSCRIPTS CITED}

Aberdeen, University of Aberdeen

MS 24: 209 n. 38, 220 n. 62, 221 n. 64, 221, 221 n. 65

Ann Arbor, University of Michigan, Special Collections Library

MS Leaf 38: 320

Baltimore, Walters Art Museum

MS W. 8: 251

MS W. 105: 187-8, 187-8 n. 1, 188 n. 2, 189 fig. 1, 190-2, 191 n. 6, 191 n. 7, 191 n. 8,192 n. 11,193 fig. 2, 194 fig. 3, 195 fig. 4, 196, 199, 201, 203, 205, 208-11, 213, 216-20, 219 fig. 12, 222-30, 222-3

n. 70, 223 fig. 13,226 fig. 14

Berlin, Staatsbibliothek

MS Or. fol. 1211: 249 n. 33

Bern, Burgerbibliothek

MS lat. 611: 335, 337-8, 343-46, $344 \mathrm{n}$. 21, 344 n. 22,345 n. 23,345 n. 24, 347 fig. 1, 348-52, 352 n. 28, 357-60, 357 n. 36,357 n. 37

Cairo, Karaite Synagogue

Gottheil 14: 245-6, 246 fig. 7, 249 n. 30, 264

Gottheil 17: 237, 237 n. 12

Gottheil 34: 231 n. 2, 248-9, 248 n. 27, 248 n. $28,257-8$ n. 56,260 n. 64,264

Cambridge, Cambridge University Library MS Gg. 1.1: 390-1, 390-1 n. 2, 391 n. 3, 391-2 n. 4, 392 fig. 1, 397 n. 9

MS Ii. 1.33: 340 n. 15
Cambridge, Trinity College

MS F. 12.70: 267

MS F. 12.71: 267

Chantilly, Musée Condé

MS 9: 298-9 n. 76

Cleveland, Cleveland Museum of Art, The Jeanne Miles Blackburn Collection 2011.51 fol. $390: 303,328,331$ n. 96

Columbus, The Ohio State University

Libraries, Rare Books \& Manuscripts

Library

Spec.Rare.MS.MR.Frag.74: 271-286, 271 n. 4,273 n. 7, 273 n. 8, 274 n. 10, 274 n. 11, 275 n. 12, 276 n. 13, 275 n. 14, 276 n. 16, 276 n. $18,276-7$ n. 19,277 n. 20,277 n. 21,277 n. $22,277-8$ n. 23,278 n. 24 , 279 n. 25,279 n. 26,280 n. 27,280 n. 28 , 280 n. 29,281 n. 30,281 n. 31,281 n. 32 , 286 n. 43, 286 n. 44,286 n. 45, 287 fig. 1 , 288-309, 289 fig. 2, 290 fig. 3, 290 n. 50, 290 n. 51,290 n. 52,291 n. 53, 292 n. 55, 292 n. 58, 293 fig. 4,296 n. 66, 296 n. 69, 297 n. 70, 297 n. 71, 298 n. 74, 299 n. 77, 299 n. 78, 299 n. 80,300 fig. 5, 301 fig. 6, 303 fig. 7, 304 n. 84, 306 fig. 8, 310-31, 310 n. 89,311 n. 90,331 n. 92

Copenhagen, Kongelige Bibliotek Cod. Heb. II: 236, 236 n. 9, 266

Cod. Heb. III: 268

Cod. Heb. IV: 268

Dublin, Trinity College Library

MS 16: 239 n. 14 


\section{Halperin: Calligraphic Frames in Sephardic Hebrew Bibles}

\section{4 | Journal for Manuscript Studies}

MS 94 (F.5.21): 191-2, 192 n. 9

MS M 2.5: 268

Frankfurt-am-Main, Stadtbibliothek olim Ausst. 4: 236, 236 n. 9

Genoa, Biblioteca Universitaria MS D.IX.31: 268

Ghent, Universiteitsbibliotheek Gent MS 92: 334 n.1

Hamburg, Staats- und Universitätsbibliothek

Cod. Hebr. 45: 242 n. 19

\section{Haverford, Haverford College}

Rendel Harris 1: 242-3, 242 n. 19, 262, 262 n. 66,265

Iowa City, University of Iowa Special

Collections xMMs.Br2: 410-1, 411 fig. 6 xMMs.Ps3: 409-11, 411 fig. 6 xMMs.Se1: 410-1, 411 fig. 6

Istanbul, Karaite Synagogue Istanbul Pentateuch: 237, 237 n. 12

Jerusalem, National Library of Israel MS Heb 4º790: 233-4, 234 n. 6, 238 fig. 4, 242, 242 n. 19, 265

MS Heb 4¹112: 265

MS Heb 45147: 237, 237 n. 12

MS Heb 86527: 236 n. 7

Kraków, Biblioteka Jagiellońska MS 1599 (DD.VI.1): 368

Kremsmünster, Stiftsbibliothek

Kremsmünster CC 243: 205, 205 n. 30, 206 fig. 7, 208

Leiden, Universiteitsbibliotheek BPL 114: 344 n. 22

Letchworth, Sassoon Collection olim MS 368: 237, 237 n. 12, 267 olim MS 508: 267
Lisbon, Biblioteca Nacional de Portugal MS I1.72: 239 n. 14

London, British Library Cotton Roll XIV.12: 210 n. 40 MS Additional 28162: 208 n. 31 MS Additional 43120: 191-2, 192 n. 9 MS Additional 54180: 208 n. 31 MS Arundel 83 II: 197 n. 14, 203, 203 n. 27, 204 fig. 6, 220 n. 61 MS Cotton Caligula A XIV: 251, 253, 253 ก. 42

MS Cotton Faustina B VII: 427

MS Harley 2253: 221, 221 n. 65

MS Harley 4751: 220 n. 63

MS Harley 5698: 268

MS Harley 5699: 268

MS Harley 5774: 267

MS Harley 5775: 267

MS Kings 1: 236-7, 236 n. 9, 241-2, 267

MS Or. 2201: 266

MS Or. 2626: 241 fig. 6, 268

MS Or. 2627: 241 fig. 6, 268

MS Or. 2628: 241 fig. 6, 268

MS Royal 2 B VII: 220 n. 63

MS Royal 10 E VII: 192 n. 9

MS Yates Thompson 13: 190 n. 5, 224 n. 73,227 n. 75

London, Lincoln's Inn MS Hale 123: 301-2 n. 81

Madison, University of Wisconsin-Madison MS 80: 410-1, 411 fig. 6 MS 170A, no. 8: 406 fig. 2

Madrid, Real Biblioteca del Palacio Real MS II, 3231-46: 268

Marseille, Bibliothèque municipale MS 1626: 266

Modena, Biblioteca Estense Universitaria MS $\propto .0 .5 .9: 267$ MS M.8.4: 236-7, 236 n. 9, 241-3 MS T.3.8: 236, 236 n. 9 


\section{Manuscript Studies, Vol. 4 [2019], Iss. 2, Art. 2}

Montpellier, Bibliothèque interuniversitaire, Section Médecine

H.196: 421-5

New Brunswick, Rutgers, The State

University of New Jersey, Special Collections and University Archives

MC 0886:13: 325

New York, The Jewish Theological Seminary of America

MS L.6: 269

MS L 44a: 265

New York, The Morgan Library \& Museum MS G. $50: 222$ n. 67

MS M.163: 299 n. 80

MS M.269: 296-7, 297 n. 70, 298 n. 74

MS M.729: 200 n. 24, 201, 201 n. 25, 202 fig. 5,219 n. 60

MS M.791: 303-4, 304 n. 84

Oxford, Bodleian Library

MS Bodley 764: 220 n. 63

MS Can. Or. 42: 267

MS Can. Or. 137: 249 n. 33

MS Douce 366: 220 n. 63

MS Kennicott 2: 238-9, 238-9 n. 14, 267

MS Lyell 71: 210 n. 40

MS Oppenheim Add. 4º75: 239 n. 14, 266

MS Oppenheim Add. 4º76: 239 n. 14, 266

Oxford, Corpus Christi College

MS 70: 192 n. 9

Oxfordshire, Wormsley Library

Burckhardt-Wildt Apocalypse fol. 5: 203, 203 n. 28,205

Paris, Bibliothèque de l'Arsenal

MS 65: 292 n. 58

Paris, Bibliothèque Mazarine

MS 895: 386 n. 100

MS 896: 386 n. 100
Paris, Bibliothèque nationale de France

MS Fr. 9220: 197 n. 14, 213, 213 n. 48, 215 n. 50

MS Hébreu 7: 234 fig. 2, 236, 236 n. 9, 239 fig. 5, 266

MS Hébreu 20: 239 n. 14

MS Hébreu 21: 235 fig. 3, 238-9, 238-9

n. $14,262,266$

MS Hébreu 25: 265

MS Hébreu 26: 265

MS Hébreu 31: 241, 267

MS Hébreu 1314: 237, 237 n. 12

MS Hébreu 1315: 237, 237 n. 12

MS Lat. 765: 192 n. 9, 192 n. 10, 227 n. 76

MS Lat. 4629: 344 n. 22

MS Lat. 9656: 341 n. 16

MS Lat. 10756 : 335, 343-46, 344 n. 21, 344 n. 22,345 n. 23,345 n. 24, 349-50, $357-8,357$ n. 38

Nouv. acq. fr. $13521: 342$ n. 19

Paris, Bibliothèque Sainte-Geneviève

MS 8: 301-2 n. 81

MS 2200: 213, 213 n. 48, 214 fig. 10, 215, 215 fig. 11

Paris, Compagnie des prêtres de Saint-Sulpice MS 1933: 237, 237 n. 12

Paris, École nationale supérieure des beaux-arts

Mn Mas. 4: 237, 237 n. 12

Parma, Biblioteca Palatina

MS Parm. 677: 268

MS Parm. 2025: 265

MS Parm. 2668: 233 fig. 1, 235-7, 236 n.

10, 261, 266

MS Parm. 2938: 239 n. 14

MS Parm. 3233: 240-1, 243, 266

Philadelphia, The Free Library of

Philadelphia

Lewis E 249 B: 211, 211 n. 44, 212 fig. 9

Lewis O 140: 240, 269 


\section{Halperin: Calligraphic Frames in Sephardic Hebrew Bibles}

\section{6 | Journal for Manuscript Studies}

Philadelphia, Science History Institute

Othmer 1: 406-9, 407 fig. 3, 408 fig. 4, 409 fig. 5

Philadelphia, University of Pennsylvania

LJS 24: 412

LJS 429: 389-90, 390 n. 1, 395-8, 396 fig 3, 397 n. 9, 398 fig. 4

Prague, Národní knihovna České republiky XIV A 13: 251, 251 n. 41

Rochester, University of Rochester

D.460 1003-003: 361-71, 361 n. 1, 363 fig. 1, 364 n. 4, 364-5 n. 5, 365-6 n. 6, 373 n. 27, 374, 375 fig. 2, 376-388, 376

fig. 3,377 n. 30,377 n. 31,377 n. 32,377 n. 33,377 n. 34,377 n. 35,377 n. 36,377

n. 37,378 n. 38,378 n. 39,378 n. 40,378

n. 41,378 n. 42,378 n. 43,378 n. 44,378

n. 45,378 n. 46,378 n. 47,379 n. 48,379

n. 49,379 n. 50,379 n. 51,379 n. 52,379

n. 53,379 n. 54,379 n. 55,380 n. 56,380

n. 57,380 n. 58,380 n. 59,380 n. 60,380

n. 61,380 n. 62,380 n. 63,381 n. 64,381

n. 65,381 n. 66,381 n. 67,381 n. 68,381

n. 69,381 n. 70,381 n. 71,381 n. 72,381

n. 73,382 n. 74,382 n. 75,382 n. 76,382

n. 77,382 n. 78,382 n. 79,382 n. 80,382

n. 81,383 n. 82,383 n. 83,383 n. 84,383

n. 85,383 n. 86,383 n. 87,383 n. 88,383

n. 89,383 n. 90,383 n. 91,383 n. 92,383

n. 93,384 n. 94,384 n. $95,384-5$ n. 96 , 385 n. 97,385 n. 98,385 n. 99

Rome, Biblioteca della Comunità Israelitica

MS 3: 237, 237 n. 12, 267
Saint Petersburg, National Library of

Russia

Evr. I B 19a: 248-9, 248 n. 27, 264

Evr. II B 17: 264

Evr. II B 116: 244

Evr. II B 168: 248-9, 248 n. 27, 249 n. 31, 264

Evr. II B 269: 264

Evr. II B 1548: 245, 245 n. 25, 247, 247

fig. 8, 247-8 n. 26, 264

Evr. II C 144: 248-9, 248 n. 27, 249 n. 31, 264

Stockholm, Nationalmuseum

MS B. 1726: 187, 187-8 n. 1, 190-2, 191

n. 7,191 n. $8,227-8$

MS B. 1727: 187, 187-8 n. 1, 190-2, 191

n. 7,191 n. $8,227-8$

Vatican City, Biblioteca Apostolica

Vaticana

MS Reg. Gr. 1: 250-1, 251 n. 37, $251 \mathrm{n}$. 39, 251 n. 40, 252 fig. 9, 253, 253 n. 43

MS Ross. 601: 241-2, 242 n. 19, 265

MS Vat. lat. 1033: 362 n. 3, 377, 382 n.

76, 384-5 n. 96,385 n. 99,386 n. 100

MS Vat. lat. 1034: 362 n. 3, 377, 382 n.

76, 384-5 n. 96,385 n. 99, 386 n. 100

MS Vat. lat. 1035: 362 n. 3, 377, 382 n.

76, 384-5 n. 96, 385 n. 99, 386 n. 100

MS Vat. lat. 1046: 362 n. 3

Vienna, Österreichische Nationalbibliothek Cod. Heb. 16: 249

Zurich, Braginsky Collection MS 243: 238-9, 238-9 n. 14, 243, 268 